\title{
EPA AND THE COURTS: TWENTY YEARS OF LAW AND POLITICS
}

\author{
Robert Glicksman* and Christopher H. Schroeder**
}

\section{INTRODUCTION}

This article examines the relationship between EPA and the federal courts during the first twenty years of the Environmental Protection Agency ("EPA"), concentrating in particular on the Court of Appeals for the District of Columbia Circuit, which hears the vast majority of challenges to major EPA decisions.

The stance of the federal courts toward the Environmental Protection Agency has changed substantially during this period. An early mix of enthusiasm for the project of environmental protection, respect for the public policy decisions of the Congress, and a rhetoric of close scrutiny of EPA's decisionmaking processes has given way to neutrality toward environmental values, skepticism about whether environmental legislation expresses coherent public policy, and a rhetoric of deference toward EPA's decisions.

This shift is apparent in both doctrinal changes and in the language of judicial opinions reviewing EPA decisionmaking. It is part of a larger reorientation of the federal courts toward judicial review of agency decisionmaking generally. During the period we study, scholarly analyses of aggressive judicial review of agency rulemaking have also moved from agreement with the judiciary's early self-evaluation that "agencies and courts together constitute a 'partnership' in furtherance of the public interest,' and are 'collaborative instrumentalities of justice,'"' to a more negative appraisal. As Peter Strauss has recently observed, "recent scholarship is tending to [view judicial review as] paralyzing" the ability of administrative agencies to carry out their statutory responsibilities, or-what is not always the same thing-to develop sound public policy. ${ }^{2}$

Copyright $\odot 1991$ by Law and Contemporary Problems

* Professor of Law, University of Kansas School of Law, Lawrence, Kansas.

** Professor of Law, Duke University School of Law, Durham, North Carolina.

1. Grealer Boston Television Corp. v FCC, 444 F2d 841, 851 (DC Cir 1970).

2. Peter L. Strauss, Considering the Alternatives to "Hard Look" Review, 1989 Duke L J 538, 549. Although the principal studies to which Professor Strauss refers have not all concentrated on judicial review of EPA, any such general evaluation of judicial review of administrative action will apply specifically to EPA. Many of the milestones of the "aggressive" judicial review of administrative action that are being critiqued are judicial decisions reviewing EPA action; EPA is the largest and most active of the environment, health, and safety regulatory agencies; over $80 \%$ of EPA's regulations are challenged in court. Gary C. Bryner, Bureaucratic Discretion: Law and Poligy in Federal Regulatory Agencies 117 (Pergamon Books, 1987) $(80 \%$ of EPA's major regulations challenged in court); Environmental Quality: Sixteenth Anmual Report 3 (Council on Environmental Quality, 1985) 
In this article, we correlate these changes to a parallel set of changes in political assumptions regarding the behavior of individuals and political institutions, some of which have been previously noted by others. ${ }^{3}$ This analysis proves relevant to a recurring question within legal theory generally: when law is at its best, is it an autonomous discipline, independent from outside influences, especially politics? Our answer, at least in the field of administrative law, is that law and politics are ineluctably connected, in that it is impossible for courts to develop legal doctrine without a set of political assumptions to guide them, and that it is ultimately impossible to evaluate the merits or demerits of aggressive judicial review (or any regime of judicial review) without also invoking some set of political assumptions. Although we do not prove the impossibility of severing that connection here, we do demonstrate that the changes in judicial doctrine, judicial rhetoric, and academic appraisal can be best explained by displaying their consistency to concurrent changes in political assumptions. This sort of connection between law and politics, while it has been taken for granted by some, ${ }^{4}$ appears directly to contradict the widely held belief that if law is to retain its integrity and social value, it must remain isolated from political influence. ${ }^{5}$ As popular as that belief may be, it rests on a misunderstanding.

Elucidating the connection between law and political assumptions does more than contribute to a theoretical debate. Defining the appropriate nature of judicial review of agency action has been one of the "persistently intriguing puzzles" in American administrative law. ${ }^{6}$ Using EPA as an important

(“CEQ, Sixteenth Annual Report") ("Fully 85 percent of EPA's regulations result in litigation.”). Thus if paralysis of administrative agencies exists, such paralysis must affect EPA.

This recent, more negative attitude is by no means universally held. Many continue to urge that the benefits of judicial review outweigh whatever negative effects one might claim it has. See, for example, Cynthia Farina, Statutory Interpretation and the Balance of Power in the Administrative State, 89 Colum L Rev 452 (1989); Alfred C. Aman, Jr., Administrative Law in a Global Era: Progress, Deregulatory Change and the Rise of the Administrative Presidency, 73 Cornell L Rev 1101 (1988); Cass R. Sunstein, Factions, Self-Interest and the APA: Four Lessons Since 1946, 72 Va L Rev 271, 287-92 (1986). Nevertheless, it is at a minimum fair to say that the general tenor of expert wisdom on the question has shifted during the 20 years of EPA's existence from nearly unmitigated support for active judicial superintendence of EPA's decisionmaking processes to something between much more cautious support and outright hostility, and that this shift has been matched in the judiciary. Because the decision in Chevron U.S.A., Inc. $v$ NRDC, 467 US 837 (1984), marks a turn away from aggressive judicial review, the more negative appraisal frequently expresses itself as approval for Chevron's general direction. See, for example, Richard J. Pierce, Sidney A. Shapiro \& Paul R. Verkuil, Administrative Law and Process 405, $522 \mathrm{nl} 135$ (Foundation Press, 1985); Colin S. Diver, Statuton Interpretation in the Administrative State, $133 \mathrm{U}$ Pa L Rev 549 (1985); Richard J. Pierce, Chevron and its Aftermath: Judicial Review of Agency Interpretations of Statutory Provisions, 41 Vand L Rev 301 (1988). Cheoron is discussed further at text accompanying notes 205-46.

3. Robert L. Rabin, Federal Regulation in Historical Perspective, 38 Stan L Rev 1189 (1986); Farina 89 Colum L Rev 452 (cited in note 2); Aman, 73 Cornell L Rev 1101 (cited in note 2); Richard B. Stewart, Reformation of American Administrative Law, 88 Harv L Rev 1667 (1975); Cass R. Sunstein Constitutionalism After the New Deal, 101 Harv L Rev 421 (1987); Cass R. Sunstein, Interpreting Stalutes in the Regulatory State, 103 Harv L Rev 405 (1989).

4. See, for example. Cass R. Sunstein, Beyond the Republican Revival, 97 Yale L J 1539, 1548 (1989) ("American public law might be understood as a set of conflicts among competing conceptions of the nature of American political life.").

5. See text at notes $39-46$.

6. Farina, 89 Colum L Rev at 452 (cited in note 2). 
example, this article argues that understanding some fundamental political assumptions materially assists in solving this puzzle. Indeed, this claim is implicit in much of the administrative law literature, which argues for particular styles of judicial review by making political arguments. ${ }^{7}$ Our intention is to make the connections explicit by describing two sets of political assumptions, one more or less in place when EPA was created, the other more or less in place today, and showing how the change from one to the other has been paralleled by a change in the doctrine and rhetoric of judicial decisions.

The current move away from aggressive judicial review cannot simply be reduced to politics, however. Changes in environmental legislation, in the nature of litigation against the agency, and in the kinds of questions EPA frequently faces in reaching its decisions have also affected the value of aggressive judicial review.

These contextual changes have also interacted with changes in political assumptions, and in more than one way. For one thing, less aggressive judicial review by the courts stimulates Congress to write ever more specific statutes, as it tries to be so specific in expressing its will that even a deferential court will be able to help police agency compliance. ${ }^{8}$

Such responses to judicial restraint can, in turn, reinforce the political arguments for deferential review, thus creating a reinforcing feedback loop. When Congress writes quite specific statutes it often finds itself making detailed trade-offs that are consistent with the view that Congress enacts specific deals hammered out among competing private interests. ${ }^{9}$ The conception of the legislative process as private deal-making then contributes to a judicial tendency to place more stock in policy fashioned in the executive than the legislature, and therefore to defer to the former. ${ }^{10}$

The adoption of more specific statutes, of course, need not necessarily be viewed as an endorsement of the political arguments for deferential review. Instead, these statutes may reflect Congress's continuing concern with agency capture, a phenomenon that aggressive review seeks to keep in check. ${ }^{11}$ Thus, whether the adoption of highly detailed statutes supports a posture of aggressive or deferential review depends largely upon the political assumptions underlying those kinds of review.

Still other of these contextual changes during the past twenty years would have diminished the value attributed to judicial review regardless of underlying political assumptions. For instance, decisionmaking on the basis of quantitative cost benefit analysis, which has become much more prevalent in the context of environmental policy since 1970, is an activity that largely

7. See, for example, Sunstein, 103 Harv L Rev at $411-12$ (cited in note 3); Richard J. Pierce, The Role of Constitutional and Political Theory in Administrative Law, 64 Tex L Rev 469, 504-13 (1985).

8. See text at notes 309-12.

9. See text at notes $164-202$.

10. See text at notes $205-42$.

11. See text at notes 99-123, and tex! following note 304. See also Richard J. Lazarus, The Tragedy of Distrust in the Implementation of Federal Environmental Law, 54 L \& Contemp Probs 311, 321 (Autumn 1991). 
must be left to the discretion of administrative agencies under many different political regimes. ${ }^{12}$ As a result, aggressive judicial review appears less worthwhile as the administrative state turns to more quantitatively sophisticated means of decisionmaking.

This article begins by tracing these and other related contextual changes in environmental statutes, litigation, and problems. It then explores the political environment within which these changes took place, contrasting the political assumptions prevalent in EPA's formative years with those in place today, and positing that the changes in these assumptions are connected to the movement from aggressive to deferential judicial review. The article concludes by evaluating judicial review by reference to both the political assumptions and contextual changes explored earlier.

II

\section{Changes in Environmental Problems, Statutes, and Litigation}

The first wave of environmental legislation was directed at the problems that were easiest to see and resolve. Burning rivers ${ }^{13}$ and lakes suffocating from massive algal blooms ${ }^{14}$ were obvious targets for remediation. The smog covering the nation's urban areas and the odors emanating from open solid waste dumps cried out for attention. ${ }^{15}$ In the face of these conspicuous ills, Congress enunciated broad declarations of intent to "protect and enhance" the nation's resources ${ }^{16}$ and to eliminate pollutant discharges. ${ }^{17}$ Just as the problems seemed obvious, so did the most effective solutions. The early legislation required EPA and the states to prohibit or control industrial and municipal discharges from both stationary and mobile sources, ${ }^{18}$ typically by imposing end-of-pipe controls. ${ }^{19} \mathrm{~A}$ direct cause and effect relationship between compliance with these limitations on pollutant discharges and a cleaner environment was simply assumed.

Twenty years later, these early assessments of the nature of both environmental problems and their resolution seem naive. First, the problems recognized and addressed in the early 1970 s have proven more obstinate than they first appeared. For example, despite the realization of significant tailpipe emissions reductions by automobile manufacturers, emissions of some automobile pollutants actually increased between 1970 and 1987.20

12. See text at notes $295-96$

13. The Cuyahoga River in Cleveland, Ohio and the Rouge River in Dearborn, Michigan were so polluted with flammable materials in the $1960 \mathrm{~s}$ and early 1970 s that they repeatedly caught fire. See United States $v$.4shland Oil and Transp. Co., 504 F2d 1317, 1326 (6th Cir 1974).

14. See Environmental Quality: Twentieth Annual Report 216 (Council on Environmental Quality, 1989) ("CEQ, Twentieth Annual Report") (referring to Lake Erie).

15. Id.

16. Air Pollution Prevention and Control, 42 USC $\$ 7401$ (b)(1) (1988).

17. Water Pollution Prevention and Control, 33 USC $\$ 1251$ (a)(1) (1988).

18. See, for example, 33 USC $\S \S 1311,1316$ (1988); 42 USC $\S \S 7410-7412,7521.7522$ (1988); Public Water Systems, 42 USC $\$ \$ 300 \mathrm{~g}-300 \mathrm{~g}-3$ (1988).

19. Sce, for example, CEQ, Twentieth Annual Report at 220 (cited in note 14).

20. Id at 8 (nitrogen oxides, from 18.1 to 19.5 million tons annually). 
Discharges of other such pollutants have been reduced, yet national health standards remain unmet in many urban areas. ${ }^{21}$ The Clean Water Act's system of point source controls undoubtedly has improved the quality of the nation's rivers and lakes, but it is now clear that nonpoint sources, which are harder to control both technologically and politically, continue to contribute heavily to surface water pollution. Second, problems undiscovered or ignored twenty years ago have since attracted attention, and they promise to be even more intractable than the first targets of environmental concern. Some, like groundwater pollution, are difficult to locate and control because of the physical inaccessibility of the resource.$^{22}$ Others, like the toxic waste sites targeted by the Comprehensive Environmental Response, Compensation, and Liability Act, ${ }^{23}$ are resistant to rapid amelioration because available resources are insufficient to determine the responsible parties and to carry out cleanup operations. Still other problems, like acid rain, cross both state and international boundaries, creating obstacles to either state or national resolution. Finally, controversy embroils the issue of whether conditions like global warming are even the subject of legitimate concern. Effective steps to redress such difficulties seem years away at best.

The federal statutes aimed at controlling pollution have undergone a corresponding metamorphosis. The initial wave of legislation has been extensively supplemented and revised to extend coverage, ${ }^{24}$ address problems previously overlooked, ${ }^{25}$ and fine-tune or redirect incomplete or unsuccessful programs. ${ }^{26}$ Recent statutory amendments also reflect Congress's view that at least part of the failure to achieve earlier statutory objectives was attributable to flaws in EPA's implementation. This legislation accordingly has sought to constrain EPA's discretion more narrowly than did earlier statutes, which contained somewhat broader delegations of authority. To combat EPA's delays in carrying out its statutory responsibilities, Congress has recently relied more heavily on deadlines for agency actions, such as the issuance of regulations. To prevent EPA from implementing statutes in a manner contrary to congressional intent, Congress has prescribed more detailed substantive criteria for EPA decisionmaking. ${ }^{27}$

21. EPA reported that during 1989 about 110 U.S. urban areas failed to meet the national ozone standard and about 50 areas did not meet the standard for carbon monoxide. Id.

22. See generally, Robert L. Glicksman \& George C. Coggins, Groundwater Pollution I: The Problem and the Law, 35 U Kan L Rev 75 (1986); David H. Getches, Groundwater Quality Protection: Setting A National Goal for State and Federal Programs, 65 Chi-Kent L Rev 387 (1990).

23. 42 USC $\S 9601-9675$ (1988).

24. See, for example, 33 USC § 1329 (1988) (1987 amendments to the Clean Water Act to manage nonpoint source pollution).

25. See, for example, 42 USC $\$ \S 6991-6991 \mathrm{i}$ (1988) (1984 amendments to the Resource Conservation and Recovery Act to regulate underground storage tanks).

26. See, for example, 42 USC $\$ \S 7501-7508$ (1988) (1977 amendments to the Clean Air Act to expedite air quality improvement in areas not yet complying with the national ambient air quality standards); Pub L No 101-549, $\S 101-111,104$ Stat 2399-2471 (1990) (1990 amendments to the Clean Air Act addressing nonattainment areas).

27. See generally Sidney A. Shapiro \& Robert L. Glicksman, Congress, the Supreme Court, and the Quiet Revolution in Administrative Larw, 1988 Duke L J 819. 
Statutory hammers have combined these two techniques by mandating regulatory results if EPA does not address a problem within a specified time. ${ }^{28}$ To provide opportunities for private enforcement in the event EPA fails to pursue statutory violations, Congress has expanded pre-existing citizen suit provisions $^{29}$ and added such provisions to statutes previously lacking them. ${ }^{30}$

A third facet of the changing landscape of environmental law is the nature of environmental litigation. The early cases involving judicial review of EPA decisions focused on the federal pesticide legislation and the Clean Air and Water Acts and sought to flesh out the content of key statutory programs. ${ }^{31}$ The volume of this kind of litigation appears to have increased, with the bulk of the cases having shifted to newer statutes like the Resource Conservation and Recovery Act ("RCRA"). ${ }^{32}$ The volume of judicial enforcement actions also has grown. From fiscal years 1972 through 1976, for example, EPA referred twenty-seven air pollution, eighty-eight water pollution, and zero hazardous waste or toxics cases to the Justice Department for civil prosecution. In fiscal year 1989 alone, referrals in these three areas rose to ninety-two, ninety-four, and $178 .{ }^{33}$ Criminal prosecutions, which did not begin until 1982, averaged thirty per year between 1986 and $1989 .{ }^{34}$ Citizen suit litigation also has expanded. In the $1970 \mathrm{~s}$, citizen suits against polluters were rare. ${ }^{35}$ Actions seeking to force EPA to perform nondiscretionary duties were more common, and sometimes resulted in major shifts in statutory direction $^{36}$ or the creation of entirely new statutory programs. ${ }^{37}$ Private citizen enforcement actions, especially under the Clean Water Act and RCRA, increased noticeably in the $1980 \mathrm{~s}^{38}$ Suits seeking compliance with nondiscretionary duties continued to be filed against EPA, though not always with the impact of some of the precedent-setting cases of the earlier period.

28. See, for example, 42 USC $\$ 6924(f)(3)$ (1988) (prohibiting disposal of hazardous wastes in deep injection wells if EPA does not issue regulations limiting such disposal before the statutory deadline).

29. See, for example, 42 USC $\$ 6972(a)(1)(B)$ (1988) (authorizing citizen suits under the Resource Conservation and Recovery Act against persons contributing to imminent hazards).

30. See, for example, 42 USC $§ 9659$ (1988) (added to Comprehensive Environmental Response, Compensation and Liability Act in 1986 Superfund Amendments and Reauthorization $\mathrm{Act}$ ). The citizen suit provisions also authorize suits to require EPA to perform non-discretionary duties. See id $\$ 9659($ a) $(2)$.

31. See, for example, Ethyl Corp. v EPA, 541 F2d 1 (DC Cir 1976); International Harvester Co. $v$ Ruckelshaus, 478 F2d 615 (DC Cir 1973); Environmental Defense Fund v Ruckelshaus, 439 F2d 584 (DC Cir 1971) ("EDF v Ruckelshaus").

32. See, for example, American Petroleum Inst. v EPA, 906 F2d 729 (DC Cir 1990); Hazardous Waste Treatment Council v EPA, 886 F2d 355 (DC Cir 1989); Mobil Oil Corp. v EPA, 871 F2d 149 (DC Cir 1989).

33. CEQ, Twentieth Annual Report at 156 (cited in note 14).

34. Id.

35. Id at 210 .

36. See, for example, $N R D C$ v Train, 8 Envir Rep Cases 2120 (D DC 1976) (resulting in the consent decree that set in motion EPA's issuance under the Clean Water Act of effluent limitations for point sources discharging toxic pollutants).

37. See, for example, Sierra Club v Ruckelshaus, 344 F Supp 253 (D DC 1972), aff'd sub nom Friv Sierra Club, 412 US 541 (1973) (requiring EPA to implement a program to prevent the deterioration of air quality in areas already complying with the national ambient air quality standards).

38. CEQ, Tuentieth . Innual Report at 210-11 (cited in note 14). 
By 1990 , then, the subjects of environmental concern seemed both more numerous and more complex than they had been during EPA's fledgling years. The magnitude and detail of the federal legislation enacted in response to these problems had evolved correspondingly and the litigation filed to interpret, implement, and enforce this legislation proceeded apace.

\section{III \\ Political Changes}

In the opinion of some, politics constitutes a threat to the integrity of legal decisionmaking. "Depoliticizing the law" was official policy of the Reagan Administration. 39 The possibility that judges might mistake political preferences for legal principles concerns law school deans, ${ }^{40}$ politicians, ${ }^{41}$ and Supreme Court nominees alike, ${ }^{42}$ and the "seduction of law by politics" is the theme of startlingly severe attacks on the entire sweep of American constitutional law. ${ }^{43}$ While the idea that law is a form of politics is typically associated with the left, ${ }^{44}$ even left-leaning thinkers occasionally assert that law can lay claim to objective truths or right answers, ${ }^{45}$ which would apparently place legal decisionmaking on much firmer ground than the shifting sands of political dispute and compromise. ${ }^{46}$

In this section, we document a broad shift in a set of political assumptions that has occurred in the past twenty years and show how that shift correlates with and helps explain changes in doctrine and rhetoric. We suggest that the best way to understand these latter changes is to see that judicial review of agency decisionmaking is necessarily premised on a set of contestable assumptions and that, as those assumptions shift, doctrines of judicial review will also change. In the following section, we argue not only that correlating politics and law provides the best explanation for why judicial doctrine has

39. See the speech by Attorney General Edwin Meese to the American Bar Association in 1985 , advocating a "jurisprudence of original intention": "A jurisprudence that seeks fidelity to the Constitution-a jurisprudence of original intention-is not a jurisprudence of political results. It is very much concerned with process, and it is a jurisprudence that in our day seeks to depoliticize the law." Reprinted in Jack N. Rakove, ed, Interpreting the Constitution 13, 19 (Northeastern U Press, 1990).

40. See Paul Carrington, Of Law and the River, 34 J Legal Educ 222, 226 (1984) ("[L]awyers like pilots must be always distrustful of themselves, on guard against the risk of mistaking their own political or social preferences for those of the law.').

41. Orrin G. Hatch, The Dangers of Political Law, 75 Cornell L Rev 1338 (1990).

42. Hearings before the Committee on the Judiciary, United States Senate, on the Nomination of Robert H. Bork to be Associate Justice of the Supreme Court of the United States, S Hrg 100 1011 , Pt 1, 103-05 (1987) (opening statement of Robert H. Bork) ("Bork Hearings").

43. See Robert H. Bork, The Tempting of America: The Political Seduction of the Law (Free Press, 1990).

44. See, for example, David Kairys, ed, The Politics of Law (Pantheon Books, 1990).

45. Ronald Dworkin, Taking Rights Seriously 81-130 (Harv U Press, 1977).

46. A great deal of legal iheory defines its central project as the "attempt to answer normative questions about what the law should be by identifying a neutral and objective decision procedure that can generate answers and that fairly filters the shared values of individuals in the community through legitimate institutional structures." Joseph W. Singer, Legal Realism Nou, 76 Cal L Rev 465, 535-36 (1988); see also, Joseph W. Singer, The Player and the Cards: Nihilism and Legal Theory, 94 Yale L J 1 (1984). 
changed, but that politics must also provide the justification for that doctrine as well. In other words, both the question "does law follow politics?" and the question "should law follow politics?" must be answered affirmatively.

\section{A. An Overview of Twenty Years of Political and Legal Change}

Politics has been described as addressing the question of "how to achieve the goal of the good person in the good state given existing conditions and the qualities of human nature."47 Any theory building on existing conditions and existing qualities of human nature must adopt some working assumptions about how participants in political life behave and how political institutions behave. Such assumptions are necessary to determine both what is desirable and what is feasible in political life. During the heyday of aggressive judicial review, the influential working assumptions included the belief that although the legislative process involved battles among interest groups, the legislature, by mediating those conflicts, was capable of synthesizing the competing interests into a purposeful, coherent public policy, and often did. ${ }^{48}$ This assumption enabled the Legal Process school to advocate judicial resolution of statutory ambiguities by reference to discernible statutory purposes. ${ }^{49}$ The assumption is reflected in the courts emphasizing their obligation to ensure that administrative action was consistent with legislative intent. ${ }^{50}$

At the same time as this optimistic view of the legislative process held sway, the administrative process was treated more skeptically: the working assumption was that regulatory agencies were all too susceptible to corruption and manipulation by organized private interests. ${ }^{51}$ Although this skepticism originated in analyses of the traditional regulatory agencies, it extended to EPA as well. ${ }^{52}$ As a result, the courts were not inclined to defer to EPA in resolving issues of environmental policy. Through review of both the substantive merit and procedural propriety of EPA's decisions, the courts sought to adjust the administrative process in order to confine agency discretion and prevent EPA's perceived vulnerability to special interests from thwarting legislative goals. ${ }^{53}$ In the environmental field, this inclination toward judicial aggressiveness was heightened by a further assumption about the aims of the good state, namely that a national consensus had developed that protecting environmental values was highly desirable. ${ }^{54}$

By the late $1980 \mathrm{~s}$, each of these assumptions had shifted dramatically. Views of the legislative process were revised under the influence of public

47. Martin M. Shapiro, Prudence and Rationality under the Constitution, in Gary C. Bryner \& Dennis L. Thompson, eds, The Constitution and the Regulation of Society 213, 213 (Brigham Young U, 1988). See also Sunstein, 97 Yale L J at 1542 (cited in note 4) ("American public law might be understood as a set of conflicts among competing conceptions of the nature of American political life.").

48. See text accompanying notes $60-98$.

49. See text accompanying notes 71-73.

50. See text accompanying notes 80-97.

51. See text accompanying notes 99-123.

52. See Lazarus, $54 \mathrm{~L} \&$ Contemp Probs at 315-17 (cited in note 11).

53. See text accompanying notes 73-97.

54. See text accompanying notes 128-40. 
choice theory. Instead of seeing legislators as rational and honest brokers seeking to fashion sound policy in a competitive political marketplace, public choice theorists posit that legislators are as apt to promote their own self interest as anyone else. ${ }^{55}$ Accordingly, congressional decisions, instead of reflecting coherent public policy, tend to redistribute wealth toward special interest groups favored by the majority voting bloc of the legislature. The earlier rhetoric of effectuating congressional intent, although still present to some degree, has been substantially supplanted by a tendency to stress a judge's obligation to refrain from intruding into the policymaking domain of the political branches of government. ${ }^{56}$ Under the Chevron decision, ${ }^{57}$ the practical effect of this self-restraint has been to defer to executive branch legal interpretations as well as policymaking. This tendency toward deference has been reinforced by a renewed confidence in the executive's accountability to the general public and its capacity to develop coherent public policy, although the rhetoric of capture theory can still be heard. ${ }^{58}$ Finally, with respect to environmental values themselves, the idea that the good state ought to prefer any particular deployment of social resources to any other has been undermined by the view that the good state should merely aggregate the individual preferences of its citizens, according them all equal status. In that case, there is no reason to treat environmental values as special. ${ }^{59}$

B. In the Beginning: Optimistic Pluralism, Agency Capture, and the Special Value of Environmental Protection

1. Optimistic Pluralism: Legislation as Coherent Public Policy. By the time EPA was established in 1970, the dominant working theory of American politics was interest group pluralism. ${ }^{60}$ Recently, the excesses of interest group pluralism have been attacked by scholars who are attempting to revive elements of civic republicanism in our country. ${ }^{61}$ However, the shift we trace is not between theories of pluralism and neorepublicanism, but rather a shift

55. See text accompanying notes 164-86.

56. See text accompanying notes 203-66.

57. Chevron U.S.A., Inc. v NRDC, 467 US 827 (1984).

58. See text accompanying notes 203-50.

59. See text accompanying notes 187-202.

60. See, for example, William N. Eskridge \& Philip P. Frickey, Legislation, Scholarship, and Pedagogy in the Post-Legal Process Era, 48 U Pitt L Rev 691, 697 (1987) ("In the 1950s, pluralism was accepted as the 'best description of our polity." "); See also Theodore Lowi, The End of Liberalism (W.W. Norton \& Co., 1978); Nicholas Miller, Pluralism and Social Choice, 77 Am Pol Sci Rev 734 (1983); John F. Manley, Neo-Pluralism: A Class Analysis of Pluralism I and Pluralism II, 77 Am Pol Sci Rev 368, 368 (1983), citing three general theories of political power-pluralism, elitism, and class analysis-and identifying pluralism as "the most widely accepted theory." Robert A. Dahl's Pluralist Democracy in the United States was first published in 1967 (Rand McNally, 1967).

61. See, for example, Sunstein, 97 Yale L J at 1542 (cited in note 4); Frank I. Michelman, Traces of Self-Government, 100 Harv L Rev 4 (1986); Suzanna Sherry, Civic Virtue and the Feminine l'oice in Constitutional Adjudication, 72 Va L Rev 543 (1986). Professor Sunstein argues, however, that public law doctrines are by no means completely consistent with interest-group pluralism; they retain many elements that are more consistent with certain republican assumptions. See, for example, Cass $\mathbf{R}$. Sunstein, Inierest Groups in American Public Law, 38 Stan L. Rev 29 (1985); Cass R. Sunstein, Public Values, Private Interests and the Equal Protection Clause, 1982 S Ci Rev 127. 
within pluralism itself, for it is this movement that has proven influential in the turn away from aggressive judicial review.

The pluralism of the 1960 s and 1970s was a critical response to theories postulating that practical power in American politics was concentrated in the hands of elites. In contrast, pluralism offered an understanding in which changing coalitions of minorities ruled from time to time and from issue to issue, without single coalitions being able to concentrate power across issues or long enough to accumulate dangerous amounts of power.

This analysis of the actual distribution of power supported two optimistic conclusions about the legislation that would issue from a pluralist polity. First, although discrete minorities might from time to time succeed in enacting patently self-serving legislation, ${ }^{62}$ legislation typically would reflect a roughly reasonable equilibrium of the relevant interests, as minority groups jockeyed and compromised in order to assemble a working majority. This result was perceived to be a fair compromise in most instances:

Every statute tends to represent compromise because the process of accommodating conflicts of group interests is one of deliberation and consent. The legislative vote on any issue tends to represent the composition of strength, i.e., the balance of power, among contending groups at the time of voting. What may be called public policy is the equilibrium reached in this struggle at any given moment. . .63

Second, while on any one issue some groups would obviously lose, changing coalitions across issues indicated that the disadvantages created by any single piece of legislation were not cumulative across all legislation. In Who Governs?, Robert Dahl asked, "Are the inequalities in resources of influence [on the political decisionmaking process] 'cumulative' or 'noncumulative'?" In a pluralist society, he concluded, these inequalities will be noncumulative, suggesting that legislative outcomes over time will not mass inequalities on any single sector or group of sectors of the society. ${ }^{64}$

The dynamics of conflict resolution mapped out by such optimistic pluralism alleviate the concern that majority rule might trample minority interests. By purporting to explain how American majoritarianism operates in practice, pluralism thus addresses James Madison's concern about majority factions. ${ }^{65}$ Dahl captured this comforting thought when he concluded that,

62. The classic example, exposed by an equally classic study, is the Smoot-Hawley Tariff of 1930. See Elmer E. Schattschneider, Politics, Pressures and the Tariff (Prentice Hall, 1935).

63. Earl Latham, The Group Basis of Politics 35 (Cornell U Press, 1952). See also Sunstein, 97 Yale LJ at 1542-43 (cited in note 4) (Under pluralism, "various groups in society compete for loyalty and support from citizens. Once they are organized and aligned, they exert pressure on political representatives, who respond, in market-like fashion, to the pressures thus exerted. The ultimate result is political equilibrium.").

64. Robert A. Dahl, Who Governs? Democracy and Power in an American City 7, 85 (Yale U Press, 1961).

65. More generally, some pluralists apparently assumed that the results of clashes of specific interests would be generally sound public policy. See, for example, Lowi, The End of Liberalism at 47 (cited in note 60) ("Pluralists believe that pluralist competition tends toward an equilibrium, and therefore that its involvement with government can mean only good. Use of government is simply one of many ways groups achieve equilibrium. Pluralist equilibrium is really the public interest."); Eskridge \& Frickey, 48 U Pill L Rev at 697 n 16 (cited in note 60). 
while the American democracy may be formally constituted to enable majority rule, "specific policies tend to be the products of 'minorities rule.' "66

If pluralism is fundamentally concerned with the interactions among groups and in the conditions for governing in contexts of dispersed power, some pluralists have been faulted for not providing adequate explanation for the role of elected and governing officials in the processes of group interaction. ${ }^{67}$ Political scientists, most notably Charles Lindblom, responded to this omission by revising pluralist theory to account for the government itself as a distinct participant in community decisionmaking. Even earlier, however, legal scholarship was developing a theory of the role of the legislator in formulating policy that proved influential in the judiciary's view of the agency-judiciary relationship. An entire generation of lawyers and judges had their understanding of that relationship shaped by the Legal Process school, largely through courses that delved into materials by the same name written by Henry Hart and Albert Sacks of Harvard Law School. ${ }^{68}$

Accepting many of pluralism's insights on the influence of interest groups on legislative outcomes, Hart and Sacks added another important ingredient: the reasonable legislator. They urged that one should assume, in the absence of specific evidence to the contrary, "that the legislature was made up of reasonable persons pursuing reasonable purposes reasonably."'69 For those who might otherwise find pluralism's belief in accommodating equilibria a little mysterious, reasonable legislators provided an explanation for how

66. Robert A. Dahl, A Preface to Democratic Theory 133 (U Chicago Press, 1956). Dahl's pluralism was much more than a wooden theory of interest group interaction. He stressed that social consensus on fundamental values was crucial to the workings of American democracy, because that consensus ensured that policy choices to be made in the formal political process were already preselected to be within a zone of acceptability to the majority of the electorate.

[T] he specific policies selected by a process of "minorities rule" probably lie most of the time within the bounds of consensus set by the important values of the politically active members of the society. ... In a sense what we describe as democratic "politics" is merely the chaff. It is the surface manifestation, representing superficial conflicts. Prior to politics, beneath it, enveloping it, restricting it, conditioning it, is the underlying consensus on policy that usually exists in the society.

Id at 132. In Dahl's view, the main guarantor of a healthy democracy was this social consensus, rather than the formal legal rules of the Constitution. Id at 134-35. In this regard, of course, Dahl's pluralism could claim roots in Madison, who told the Virginia Ratifying Convention that "[ $t] 0$ suppose that any form of government will secure liberty or happiness without any virtue in the people, is a chimerical idea." Jonathan Elliott, III, The Debates in the Several State Conventions on the Adoption of the Federal Constitution 537 (Burt Franklin reprints, 1974).

67. See, for example, Theda Skocpol, Bringing the State Back In: Strategies of Analysis in Current Research, in Peter B. Evans, Dietrich Rieschmeyer \& Theda Skocpol, eds, Bringing the State Back In (Cambridge U Press, 1985); Grant Jordan, The Pluralism of Pluralism: An Anti-Theory, 38 Pol Stud 286, 292 (1990) (contrasting Charles Lindblom's attention to the role of government with its neglect by others); Martin Smith, Pluralism, Reformed Pluralism and Neopluralism: the Role of Pressure Groups in Policy Making, 38 Pol Stud 302, 308 (1990) ("The major pluralists' studies of policy-making . . concentrate on the behavior and organization of groups and so pay insufficient attention to the interests and activities of the bureaucracy and government. They do not fully recognize the ability of state actors to make policy autonomously of groups.").

68. William Eskridge and Philip Frickey provide an excellent summary of the influence of the Legal Process school on law professors' understanding of the legislative process. Eskridge \& Frickey, 48 U Pitt L Rev at 694-701 (cited in note 60).

69. Henry Hart \& Albert Sacks, The Legal Process 1414-15 (Cambridge, tentative edition 1958). 
diverse interest group inputs were digested and translated into coherent public policy.

Within the Legal Process paradigm, the legislature, at least some of the time, performs a special kind of mediation role. Not only does the legislature provide a venue in which competing interests might be traded off until some compromise is reached, but lawmakers also synthesize the competing points of view into a purposeful resolution of the conflict. These purposes in turn give the courts "law to apply" beyond the specific, articulated details of the statutory scheme. ${ }^{70}$

Any statute written in general language will confront questions of detail and application not expressly resolved by the language itself. Whenever this occurs, the judge needs to decide how to proceed. The Legal Process school, as well as most of the Legal Realists before that, believes it legitimate for courts to decide such cases in light of statutory purposes. Doing so is thought thoroughly consistent with the principle that legislators make laws and judges merely apply them, for it is assumed that a reasonable legislator would want, indeed insist, that her statutes and rules be interpreted in light of her purposes. She would so insist because, unless she acted arbitrarily, she in fact enacted the statutes and rules with criteria or purposes in mind, which she thinks superior to any substitutes. ${ }^{71}$ In circumstances where the statute does

70. Eskridge and Frickey stress that the Hart and Sacks assumption that legislators are reasonable "was critically important . . because it affirmed the objectivity, indeed the legitimacy, of legal rules." Eskridge \& Frickey, 48 U Pitt L Rev at 695 (cited in note 60). That assumption, however, only affirms the legitimacy of legal rules that purport to reason from purposes, as in fact many judicial opinions do. Originalists offer another view of the purposes-objectivity relationship, one which might be termed a rule of parsimonious construction: because legislation has no purpose other than to seal interest group deals, the only objectively correct manner for a judge to resolve some question of interpretation is to choose the result that best leaves private conduct untouched by the statute. This rule may be considered objective, given the premises of the argument, namely a presumption in favor of private autonomy and an assumption of an irrational legislative process. Thus the reasonableness assumption is not necessary for the defense of any legal rule as objective, but only for such a defense of rules that purport to reason from purposes.

71. James Gordley, Legal Reasoning: An Introduction, 72 Cal L Rev 138, 142 (1984). Gordley argues for a stronger proposition than is necessary for present purposes. He argues that even when a statute is susceptible to a "mechanical" interpretation that "appl[ies] relevant rules in a logically rigorous argument," id at 140, a legislator who believes the statute was justified by some nonarbitrary set of purposes or criteria would acknowledge that not following the statutory rules may from time to time be more consistent with those purposes or criteria than following them. In such cases, following or deviating from the rules should be a matter decided by the criteria and purposes of the legislator-including, of course, criteria relevant to the question of whether deviating from the rule is worse than following it, even though the specific case would come out differently if the purposes and not the rule were followed. Such a course "should" be followed because that is the course such a legislator would herself prefer.

Indeed, [the] interpreters [of such a legislator] have no right to interpret their authority mechanically and claim any validity for their result, since that is not how [the legislator] wished to be interpreted. What they must do instead, when confronted with a set of rules, is to ask by what criterion the rules were made. With this criterion in mind, they can be alert for cases that would come out wrong according to the criterion though right according to the rules. When these cases arise, they can ask whether their authority considered the advantages and disadvantages of deviating from the rules to allow for the special circumstances of the case. If he did not, they can consider the matter for themselves and act accordingly.

Id at 145 . 
not speak clearly, a legislator who enacted a statute with such discernible criteria or purposes in mind would want the interpretational question resolved by reference to those criteria or purposes, rather than in some other way.

Clearly, for this interpretational approach to be available to judges, there must be purposes to apply. The assumption of reasonable legislators acting reasonably sanctions the judicial search for those purposes, for it posits that these purposes will often be present. ${ }^{72}$ The objective of judicial review of agency action, therefore, is to define the limits of agency discretion afforded by statutory delegations, in light of underlying statutory goals, and to ensure that agencies such as EPA act within the bounds of those limits. ${ }^{73}$

Exactly what judges should do to ensure agency fidelity to statutory purposes was debated throughout the late 1960s and into the 1970s. Some judges, such as Judge David Bazelon, favored confining EPA's discretion solely through strengthening administrative procedures. ${ }^{74}$ Others advocated careful review of the substantive propriety of EPA's decisions. The latter camp included Judge James Oakes of the Second Circuit, who remarked in 1977 that "a substantive judicial role is absolutely essential if judges are to meet their serious constitutional obligation to check abuses of agency discretion."75 Another forceful champion of this view was Judge Harold Leventhal. Although he conceded that "giving up" on the task of serious substantive review would be an easy way out of the conundrum created by the need to decide cases that could not be resolved by resort to the statutory text, he insisted that this option was not legitimate. Substantive review was a responsibility imposed on the courts by Congress, which had agreed to make broad delegations of authority to agencies like EPA only because there is judicial review "to assure that the agency exercises the delegated power within statutory limits."76 References to the courts' "responsibility" to review EPA decisions to ensure consistency with legislative intent abound in the early cases, in the context of deciding both statutory interpretation ${ }^{77}$ and statutory implementation issues. ${ }^{78}$ One judge indicated in the latter context, for

72. See Cynthia Farina's analysis of the delegation doctrine decisions, arguing that the Court's insistence that Congress articulate identifiable principles is necessary to maintain a distinction between making and interpreting law. Such principles, which include purposes, provide a basis for both agency and judicial interpretation. Farina, 89 Colum L Rev at 478-99 (cited in note 2). For judicial application of this idea, see text accompanying note 84-88.

73. EDF $v$ Ruckelshaus, 439 F2d at 593, 598 .

74. Ethyl Corp., 541 F2d at 66-68.

75. James L. Oakes, Substantive Judicial Review in Environmental Law, 7 Envir L Rptr 50029, 50030 (1977).

76. Ethyl Corp., 541 F2d at 68. See also Harold Leventhal, Environmental Decisionmaking and the Role of the Courts, 122 U Pa L Rev 509, 555 (1974) ("The courts have been selected by Congress to provide an 'independent review' of the decisions involved."). Indeed. Judge Leventhal hinted that the courts would have to apply the nondelegation doctrine more rigorously if the courts' obligation to engage in substantive review were not taken seriously. See Ethyl Corp., 541 F2d at 68.

77. International Harvester, 478 F2d at 633; EDF $v$ Ruckelshaus, 439 F2d at 596.

78. Environmental Defense Fund v EPA, 465 F2d 528, 540-41 (DC Cir 1972) ("EDF $v E P A ")$; Kennecolt Copper Corp. v EPA, 462 F2d 846, 848 (DC Cir 1972); Scenic Hudson Preservation Conf. v FPC, 354 F2d 608, 612 (2d Cir 1965). 
example, that "[a] court would abdicate its function" if it did not set "parameters of rationality within which the agency must operate."79

In the early cases involving challenges to EPA's interpretation and implementation of statutes, the courts routinely referred to the underlying legislative "purposes" to resolve those challenges. According to Judge Leventhal, "[i]n ascertaining congressional intent we begin with the language of the statute, but this is subject to an overriding requirement of looking to all sources including purposes and legislative history, to ascertain discernible legislative purpose." 80 Ascertaining such a purpose took priority not only over the policy of upholding reasonable interpretations by agencies in the absence of "other discernible legislative intent," 81 but even over adherence to the plain meaning doctrine. ${ }^{82}$

Though they recognized that Congress had been forced by the scope and complexity of the task at hand, and by its inability to foresee all possible contingencies, to delegate broadly to agencies charged with implementing environmental protection statutes, the courts nevertheless ascertained "benchmarks" to guide agencies and courts in determining whether or not the former were exceeding their powers. ${ }^{83}$ Although it did not involve EPA, the landmark Overton Park ${ }^{84}$ case set the tone for this kind of analysis in future environmental disputes. The plaintiffs claimed that the Secretary of Transportation's decision to finance the construction of a highway through a public park violated a statute that permitted such construction only in the absence of feasible and prudent alternatives to the use of park land. The secretary argued that the statute vested in him considerable discretion on the issues of "prudence" and "feasibility" and that the courts should defer to the exercise of that discretion. The Court, however, perceived in the legislation a desire to elevate the protection of park land to a level of "paramount importance." 85 The Court thus interpreted a statute that arguably required the secretary to balance a variety of factors" 86 as leaving to him "only a small range of choices"87 - highways could be routed through parks only in the most unusual situations. Given that limited discretion, the Court concluded

79. South Terminal Corp. v EPA, 504 F2d 646, 665 (1st Cir 1974).

80. Portland Cement Ass in v Ruckelshaus, 486 F2d 375, 379-80 (DC Cir 1973).

81. International Harvester, 478 F2d at 639.

82. Portland Cement Ass 'n, 486 F2d at $380 \mathrm{n} 13$ (" "The "plain meaning" doctrine has always been subservient to a truly discernible legislative purpose however discerned,' by equitable construction or recourse to legislative history."), citing Wilderness Society v Morton, 479 F2d 842 (DC Cir 1973); District of Columbia v Orleans, 406 F2d 957, 959 (DC Cir 1968). See also Getty Oil Co (Eastern Operations) $v$ Ruckelshaus, 467 F2d 349, 356 (3d Cir 1972), where the court noted its agreement with "Justice Frankfurter's admonition that '[s]tatutes . . . are instruments of government, and in construing them "the general purpose is a more important aid to the meaning than any rule which grammar or formal logic may lay down." This is so because the purpose of an enactment is embedded in its words even though it is not always expressed in words." ", quoting United States $v$ Shirey, 359 US 255, 260-61 (1958).

83. South Terminal Corp., 504 F2d at 677.

84. Citizens to Preserve Ouerton Park, Inc: v Volpe, 401 US 402 (1971).

85. Id at $412-13$.

86. See Harry J. Kalen, Jr., The Supreme Court, 1970 Term, 85 Harv L Rev 3, 324 (1971).

87. Citizens to Preserve Overton Park, 401 US at 416. 
that the secretary had not justified adequately his departure from the basic goal of park land protection. ${ }^{88}$

The lower courts soon followed the lead of Overton Park by engaging in similar efforts to ferret out overarching statutory purposes. For example, the District of Columbia Circuit was called upon to assess the legality of EPA's regulations limiting the lead content of gasoline, issued under a provision of the Clean Air Act authorizing regulation of additives that "will endanger" the public health or welfare.89 The issue was the quantum of proof of endangerment required to justify regulation, a matter that the statute did not resolve explicitly. The court upheld the regulations despite the absence of a threshold factual finding that the uncontrolled emissions would cause harm, because, in the court's view, the "policy guidelines . . . largely set, both in the statutory term 'will endanger' and in the relationship of that term to other sections of the Clean Air Act," supported regulation. ${ }^{90}$

Once they ascertained the "public policies" that permeated a statutory scheme, the courts in the early cases displayed little reluctance to apply those policies to situations that Congress itself never considered. One such case involved review of EPA's refusal to grant to automobile manufacturers a oneyear suspension of emission standards. ${ }^{91}$ According to the court, Congress did not specifically address the question of whether such a suspension would be appropriate when a refusal to grant it would cause grave economic harm, whereas a grant would probably cause minimal environmental damage. This congressional silence, however, required neither blind deference to the balance struck by EPA nor judicial paralysis:

\begin{abstract}
As we see it, the issue must be viewed as one of legislative intent. And since there is neither express wording or [sic] legislative history on the precise issue, the intent must be imputed. The court must seek to discern and reconstruct what the legislature that enacted the statute would have contemplated for the court's action if it could have been able to foresee the precise situation. It is in this perspective that we have not flinched from our discussion of the economic and technological risks inherent in a "wrong decision" by the Administrator. ${ }^{92}$
\end{abstract}

In another case, the issue was whether EPA was exempt from the National Environmental Policy Act's ("NEPA's") requirement to prepare an environmental impact statement in issuing emission standards for new stationary sources under the Clean Air Act. ${ }^{93}$ The court concluded that EPA was exempt because, even though there was no evidence that Congress considered the precise question, an exemption would best serve NEPA's main purpose of protecting the environment. ${ }^{94}$ In the process, the court quoted

\footnotetext{
88. Id at 419.

89. Ethyl Corp., 541 F2d at 1 .

90. Id at 29 .

91. International Hariester, 478 F2d 615.

92. Id at 648 .

93. Portland Cement Ass in, $486 \mathrm{~F} 2 \mathrm{~d}$ at 375.

94. Id at 383 . Requiring an impact statement, in the court's view, presented the danger that opponents of environmental protection would use the issue of compliance as a delay tactic. Id at
} 384. 
Justice Harlan's guiding "axiom" that, "courts should endeavor to give statutory language that meaning that nurtures the policies underlying legislation ... when circumstances not plainly covered by the terms of the statute are subsumed by the underlying policies to which Congress was committed."'95 In like fashion, the Supreme Court relied in part on the Clean Air Act's underlying objective of "technology forcing" to conclude that EPA lacked the authority to reject a state implementation plan under that act on the grounds that it was economically or technologically infeasible. ${ }^{96}$ That the courts need not resort to the agency to supply the "law to apply" in such situations seemed obvious. ${ }^{97}$ Indeed, the courts recognized that reliance on the agency to supply the law ran the risk of subverting the policies discernible in statutory enactments, since the agency might elevate some of the competing interests fused in the legislative crucible at the expense of others.

In summary, in the early years of EPA, an optimistic brand of pluralism was the reigning political theory in the United States. The theory lent a soothing imprimatur to the actions of legislatures, indicating that the interests of competing groups could be melded together in a coherent fashion to produce moderate, conflict reducing, public policy. As we have seen, the theory was incorporated into judicial attitudes toward legislation, which were treated as generally coherent, purposive acts that simultaneously reflected competing interests and composed them into reasonable treatments of their subject matter. This understanding of the nature of politics underwrote aggressive judicial review of agency decisions. ${ }^{98}$

2. Agency Capture. While optimistic pluralism plays an indispensable role in understanding the political theory of the judiciary during EPA's earliest days, it is by no means the complete picture. Running alongside it was the much more gloomy theory of agency capture. While optimistic pluralism was either a general theory of governance in a society of dispersed power and interest groups with overlapping interests or else a theory that concentrated on legislative decisionmaking, agency capture theory concentrated on

95. Id at 383 n36. See also id at 380 ("In statutory interpretation, the courts must often, in effect, consider what answer the legislature would have made as to a problem that was neither discussed nor contemplated.").

96. Union Electric Company $v$ EPA, 427 US 246, 268-69 (1976).

97. See Panel, Environmental Decision-Making: The Agencies Versus the Courts, 7 Nat Res L 339, 356 (1974) (remarks of Judge Leventhal) (Courts in environmental cases serve the important function of "providing a larger perspective, a coordinating perspective of the balancing" of legislative policies.).

98. In this section, we have been summarizing general tendencies, not universal rules. Even in EPA's earliest years, the federal judiciary was thoroughly aware that significant provisions of important legislation, including environmental legislation, may be the result of many considerations other than a clear-headed resolution of public purpose. Judges realized that statutes may embody Congress's "quick answer. . . to a legislative stalemate," Industrial Union Department, AFL-CIO v Hodgson, 499 F2d 467 (DC Cir 1974), or they may reflect a deliberate delegation of policymaking authority to the agency, or they may indicate that Congress failed to perceive an issue that has subsequently emerged as significant. Granting this, the opinions of the early 1970s suggest that judges approached questions of statutory interpretation with something like a rebuttable presumption that they could discern the correct resolution from a combination of express statutory language, statutory structure, and statutory purpose. 
decisionmaking within the bureaus and administrative agencies that had become indispensable to the operations of the federal government since the New Deal.

The administrative state had been born at a time of national crisis, as agencies charged with managing the economy had been thought essential to the recovery from the Great Depression. It then passed through a period of relatively enthusiastic acceptance as a permanent, meliorating addition to the structures of government. By the 1970 s, however, that enthusiasm had worn very thin. After beginning sporadically in the 1950s, the attacks on the regulatory state that were later assembled under the umbrella of "agency capture" became "widespread and profound" in the 1960s. ${ }^{99}$

Capture theorists argued that transferring governmental authority into the hands of regulatory agencies would, sooner or later, put the foxes in charge of the chicken coop. Capture theory began with a set of trenchant empirical observations about how older regulatory agencies had evolved from agencies allegedly charged with ensuring the public interest against the predations of the regulated industry, to commissions that developed a deep stake in the well-being of the regulated industry itself and thus began to be at least as protective of and beneficial to the objects of their regulation as they were to the public at large. ${ }^{100}$

By the 1960s, the empirical studies of agency performance still remained without a completely convincing account of why capture occurred. Mancur Olson's seminal study of "the logic of collective action" 101 provided these analyses with just such a statement of the underlying mechanism of, and hence explanation for, the process whereby bureaus "came to be conceived of as a method of subsidizing private interests at the expense of public good." 102 Olson observed that large groups of individuals, each of whose stake in the results of collective action may be quite small, are at a distinct disadvantage compared to smaller groups of more intensely interested individuals. For the former, the problem of free-riding and the costs of coordination may make collective action quite difficult, whereas groups of the latter description will more easily surmount these difficulties.

When applied to the administrative state, the logic of collective action proved devastating. Concerted, sustained action in the administrative arena earns great rewards for the group that can engage in such activity. The group becomes familiar with the procedures and workings of the bureau, friendly with its staff, and perhaps relied upon for information and even advice. Its arguments and concerns become familiar to the bureaucrats. Such groups are

99. John Wiley, A Capture Theory of Antitrust Federalism, 99 Harv L Rev 713, 723 (1986). See generally, Robert C. Fellmeth, The Interstate Commerce Comission: The Public Interest and the ICC (Grossman, 1970).

100. For example, Marver H. Bernstein, Regulating Business by Independent Commission 86-95 (Princeton U Press, 1955); Gabriel Kolko, The Triumph of Conseriatism 3, 59, 283 (Quadrangle Books, 1963).

101. Mancur Olson, Jr., The Logic of Collective Action (Schocken Books, 1965).

102. Wiley, 99 Harv L Rev at 723 (cited in note 99). 
also able to hire more effective counsel and experts than more diffuse groups. The cumulative result of these advantages, all the product of these groups' cohesiveness, is that bureau decisions tend to favor the small, concentrated group. 103

Capture theorists developed their arguments by studying the older economic regulatory agencies. Generally, these agencies operated under statutes from the New Deal era or earlier that charged them to administer affairs "in the public interest." As the regulatory arena became visualized as a battleground in which competing economic interests vied for interpretive superiority concerning general statutory mandates, it became easy for observers, including judges, to see how the dynamics of the capture theory had room to operate. Courts began to view agency proceedings with suspicion, and the bureaucracies' assertions that they were watching out for the interest of the disorganized public were no longer taken as dispositive. As the District of Columbia Circuit said in. Office of Communication of the United Church of Christ v. FCC:

The theory that the Commission can always effectively represent the listener interests in a renewal proceeding ... is one of those assumptions we collectively try to work with so long as they are reasonably adequate. When it becomes clear, as it does to us now, that it is no longer a valid assumption ... neither we nor the Commission can continue to rely on it. ${ }^{104}$

EPA did not escape this increasingly suspicious judicial mind-set. Legislators, judges, and academics alike called for judicial "supervision" 105 of EPA's performance to combat the agency's susceptibility to capture by special interests whose objectives did not coincide with legislative policy. Because "[i]t cannot be assumed that EPA will always be the good guy,"106 judicial review would enable the courts in appropriate circumstances to "police the police." 107 According to Judge Leventhal, Congress empowered the courts to oversee the exercise of EPA's delegated power because a "court, isolated as it is from political pressures, ... would be a more suitable forum for review than

103. See Stewart, $88 \mathrm{Harv}$ L Rev at $1685-88,1713-15$ (cited in note 3).

104. Office of Communication of the United Church of Christ v FCC, 359 F2d 994, 1003-04 (DC Cir 1966).

105. Leventhal, $122 \mathrm{U} \mathrm{Pa} \mathrm{L} \mathrm{Rev} \mathrm{at} 511$ (cited in note 76); Panel, 7 Nat Res L at 352 (cited in note 97) (remarks of Judge Leventhal).

106. Porlland Cement Ass in, 486 F2d at 384, quoting 118 Cong Reg 16878, 16887 (Oct 4, 1972) (remarks of Sen. Jackson).

107. Id. The court also quoted from the 1972 National Wildlife Federal Conservation Report: "it cannot be forgotten that EPA is a regulatory agency and in the past in Washington almost all regulatory agencies have eventually come under the control of those that they are charged with regulating." Id at $384 \mathrm{n} 39$. The same concern surfaced in the literature. See, for example, Richard B. Stewart, The Development of Administrative and Quasi-constitutional Law in Judicial Review of Environmental Decisionmaking: Lessons from the Clean Air Act, 62 Iowa L Rev 713, 719-20 (1977) (the dedication of EPA's pesticide division to the statutory goal of environmental protection is suspect because it is a spinoff of the Agriculture Department, which was historically insensitive to environmental concerns). See also Richard B. Stewart \& James E. Krier, Environmental Law E Policy 620-21 (Bobbs-Merrill, 1978) (Agencies making decisions involving competing values are increasingly viewed as biased in favor of certain interest groups, creating pressure on courts "to go beyond the traditional model of judicial review in order to control agency discretion in policy making."). 
even the Congress." 108 While EPA may depart from statutory directives because of pressure applied by either industry-based or environmentalist interest groups, ${ }^{109}$ the courts, at least in some of the federal circuits, ${ }^{10}$ seemed more concerned about the agency's proclivity to give insufficient weight to the concerns of environmental interests. ${ }^{11}$

Once the assumption that an agency would fairly represent the interests of the unorganized public had been dropped, the dominant response of the federal judiciary was to seek means to introduce more adequate forms of representation into the administrative process. A variety of doctrinal developments in the 1960s and 1970s had this effect, including expanding the range of legally protected interests recognized under the doctrines of standing and permitting surrogate standing. ${ }^{112}$ These new representatives of the public also needed effective access to the bureaucratic proceedings that preceded judicial review. Accordingly, the courts expanded intervention rights and suggested that disorganized interests might even be able to compel an agency to initiate an administrative proceeding. The 1965 Scenic Hudson Preservation Conference v. FPC case, in which the Second Circuit reviewed the Federal Power Commission's issuance of a license to build a hydroelectric plant in a scenic area along the Hudson River, set the stage for these developments. ${ }^{13}$ In overturning the agency's licensing decision for failure to engage in a complete study of alternatives, the court stated that it would require agencies purporting to represent the public interest to act affirmatively to protect the rights of the public. ${ }^{114}$ The courts later extended this notion that environmental interests might be underrepresented in agency deliberations into the context of judicial review of EPA decisions, even though the primary mission of EPA, unlike those of development-oriented agencies such as the FPC, was protection of the environment. ${ }^{115}$

108. International Harvester, 478 F2d at 633. See also, William F. Pedersen, Formal Records and Informal Rulemaking, 85 Yale L J 38, 60 (1975) (noting that courts alone have the freedom from political considerations that is necessary to a dispassionate and effective review of complex and controversial environmental issues).

109. Leventhal, $122 \mathrm{U} \mathrm{Pa} \mathrm{L} \mathrm{Rev} \mathrm{at} 531$ (cited in note 76) (The “dominant question" for a court reviewing action taken by an environmental agency is whether there has been sufficient consideration of nonenvironmental factors.); Stewart, 62 Iowa L Rev at 725 (cited in note 107) (Judicial review under the Clean Air Act has enlarged EPA's discretion by requiring consideration of economic and social costs of controlling pollution.). See also text accompanying note 159.

110. See text accompanying notes 153, 159.

111. See, for example, note 107.

112. For a summary of these doctrinal changes, see Stewart, 88 Harv L Rev at $1723-48$ (cited in note 3).

113. Scenic Hudson, $354 \mathrm{~F} 2 \mathrm{~d}$ at 608 .

114. Id at 620 .

115. See Stewart \& Krier, Environmental Law E Policy at 621 (cited in note 107), contending that in order to respond to charges of agency bias in favor of regulated industries, courts sought to ensure the representation of all affected interests, including environmental and other loosely organized "public interests," in agency decisional processes. The courts' aim was "to enhance agency responsiveness to all of the various constituencies with a stake in their decisions." Id. See also Stewart, 62 lowa L Rev at 719 (cited in note 107); Panel, 7 Nat Res L at 369 (cited in note 97) (remarks of Grant P. Thompson) (Judges take their role in reviewing agency decisions involving environmental issues seriously, in part because these issues "affect people unrepresented, generations unborn, and ecosystems without a vote."). 
In order to level the playing field between industry and environmentalist concerns, thereby reducing the prospects for agency capture, the courts indicated that they would "go further" than in other contexts "in requiring the agency to establish a decisionmaking process adequate to protect the interests of all 'consumers' of the natural environment." 116 Accordingly, the courts steeped themselves in the process of assessing the adequacy of EPA's procedures, and often found them wanting. They required EPA, for example, to disclose for comment the data and methodology relied upon in formulating a proposed rule, 117 to expand the administrative record by providing detailed statements of its reasoning along with proposed and final rules, ${ }^{118}$ to respond to significant comments received in response to proposed rules, ${ }^{119}$ and to afford opportunity for cross-examination of witnesses, ${ }^{120}$ even though they conceded in some instances that these requirements could not be traced either to the Administrative Procedure Act or to any of EPA's organic statutes. 121

These procedural innovations were designed to improve the logic and coherence of agency decisionmaking, to ensure, insofar as procedures can accomplish this, that the agency had taken a "hard look" at the full range of affected interests before acting, ${ }^{122}$ and to facilitate judicial review. ${ }^{123}$ All of these mechanisms would assist the courts in preventing the agency from derailing the achievement of the protective initiatives reflected in the early environmental legislation.

3. Environmental Values as Special. In 1975, Richard Stewart published an important analysis of administrative law, in which he argued that the combination of the political theories of agency capture and interest group pluralism had already precipitated a "reformation" of administrative law from its earlier New Deal and Post-World War II beginnings. In addition, he argued that we had become disabused of the view that the legislature could write discernible public values and principles into law that the courts could

116. International Harvester, 478 F2d at 651. See also Ruckelshaus, 439 F2d at 594-95 (requiring public hearing into whether pesticide registration should be suspended so that the public could be brought into the decisionmaking process).

117. See Portland Cement Ass $n, 486$ F2d at 392-94; International Harvester, 478 F2d at 631-32.

118. South Terminal Corp., 504 F2d at 665; Portland Cement Ass' $n, 486$ F2d at 384-86; Kennecott Copper Corp., 462 F2d at 849; EDF v Ruckelshaus, 439 F2d at 596.

119. Portland Cement Ass' $n, 486$ F2d at 394.

120. International Harvester, 478 F2d at 649.

121. Portland Cement Ass'n, 486 F2d at 386, $400 \mathrm{n95}$; International Harvester, 478 F2d at 651-52; Kennecott Copper Corp., 462 F2d at 850 \& n 18 (in particular cases, fairness may require more than the minimum procedures specified in the APA).

122. The term "hard look" was coined by Judge Leventhal in Greater Boston Television Corp. 444 F2d at 851. Environmental decisions quickly became one of the major areas in which hard look review was applied vigorously. See generally Leventhal, 122 U Pa L Rev 509 (cited in note 76). A succinct summary of the elements of hard look review is contained in Cass R. Sunstein, Deregulation and the Hard-Look Doctrine, 1984 Sup Ct Rev 177, 181-84.

123. International Harvester, 478 F2d at 651; Pederson, 85 Yale L J at 77 (cited in note 108). See also Panel, 7 Nat Res L at $369-70$ (cited in note 97) (remarks of Grant P. Thompson) (increased procedural requirements help to expose sloppy decisionmaking to public criticism and to encourage openness and reasoned analysis). 
then superintend. As he put it, "[e]xposure on the one hand to the complexities of a managed economy in a welfare state, and on the other to the corrosive seduction of welfare economics and pluralist political analysis, has sapped faith in the existence of an objective basis for social choice."124 This loss of faith translated into a new view of administrative discretion. Because we "doubt[ed] the very existence of an ascertainable 'national welfare' as a meaningful guide to administrative decision," we had begun to view the exercise of that discretion "as the essentially legislative process of adjusting the competing claims of various private interests affected by agency policy."'125

By interpreting theories of capture and pluralism in this way, however, Stewart had gotten ahead of the historical story. He was anticipating a more radical shift in political assumptions than had yet taken place within the judiciary or within the broad spectrum of political analysis throughout the country. Specifically, throughout the 1960s and well into the 1970s, the country developed and maintained a commitment to environmental protection as a significant public value, one not reducible to the agenda of special interests intent on capturing administrative agencies.

In their initial formulations, neither pluralist nor capture theories had anything to say about whether the values being pursued in the political arena were truly public values or merely aspects of some private agenda. Each began as an empirical theory of decisionmaking in situations of value conflict, taking the existence of pluralistic disagreement as a fact and exploring how decisions are made in the face of the conflicts that a pluralistic society produces. ${ }^{126}$ As theories of conflict resolution, neither necessarily took a position on the origins or status of those conflicting values. In particular, neither theory presupposed that values are subjective or exclusively private, although individual pluralist or capture theorists may in fact have embraced the public choice claim that all values are necessarily subjective. ${ }^{127}$

Indeed, such agnosticism probably eased the assimilation of both theories into mainstream political thought, because notwithstanding the sophistication

124. Stewart, 88 Harv L Rev at 1683 (cited in note 3).

125. Id.

126. See text accompanying notes $62-66,99-103$

127. See, for example, Wiley, 99 Harv L Rev at $725 \mathrm{n} 58$ (cited in note 99) (tracing the public choice argument to the work of Kenneth Arrow). The idea that there are no objective values, and hence no objective bases for social choice, is a claim about the status, or ontology, of values that has become closely identified with the theory of public choice. Public choice theory attempts to "[apply] economics to political science. The basic behavioral postulate of public choice, as for economics, is that man is an egoistic, rational utility maximizer." Dennis C. Mueller, Public Choice: A Survey, $14 \mathrm{~J}$ Econ Lit 395 (1976), reprinted in James M. Buchanan \& Robert D. Tollison, eds, The Theory of Public Choice - II 23, 23 (U Mich Press, 1984). Within that paradigm, any values that influence an individual's choices are connected to his or her utility in ways that are determined subjectively by that individual. Even when an individual is thinking about so-called "public issues," the value he or she places on any particular resolution of the issue connects to his or her utility in a subjectively determined way. There are, on this account, no objective values.

Lately, the public choice idea and the pluralist and capture theory lessons about the mechanisms of collective action have merged into a new breed of pluralist theory, which can be labelled "pessimistic pluralism." This phenomenon is described at text accompanying notes 164-76. 
of many academics and judges in appreciating capture theory and in accepting pluralism, in EPA's early years, the "public interest" was still considered a coherent concept, and environmental values were still widely viewed as being a crucial part of that public interest. ${ }^{128}$ Environmental values were viewed as "special," but in the old-fashioned sense of distinct or unique. The environment had not yet been downgraded in status to that of just another private interest. ${ }^{129}$

The special status of environmental values had three distinct elements. First, retrieving or maintaining high environmental quality was thought to be in everyone's interests. Like national defense, and unlike the distribution of broadcast licenses, the aspect of environmental quality emphasized most was that it was a public good, valued and to be valued by everyone. As Judge Bazelon reminded his colleagues in a case challenging regulation under the Clean Air Act, "we are dealing here not with an airline's fares or a broadcaster's wattage, but with all humanity's interest in life, health and a harmonious relationship with the elements of nature."130

This is not to deny that some groups benefitted more than others from decisions to improve environmental quality or from the particular implementation strategies chosen. Again, the situation is similar to national defense, where decisions whether to upgrade the Navy or the Air Force will differentially benefit the Electric Boat Company or McDonnell Douglas. The existence of private benefits does not, however, vitiate the status of national defense as a public value. Thinking it does would, among other things, be inconsistent with the conceptions of the Constitution's framers. Madison, for instance, believed that citizens could deliberate upon and choose directions that conduced to the "collective and permanent welfare." Yet Madison knew that policies pursuing that welfare would benefit some people in society more than others. For example, he predicted that substantial inequalities of wealth would result in a country that respected individual liberty-and liberty was certainly one necessary ingredient in the country's collective and permanent welfare. ${ }^{131}$

Analogously, improving environmental quality was thought to be a direction in which we should move for the good of the country as a whole. This belief was reflected in public opinion polls. "Environmental protection had become a consensual issue by 1970 , as majorities of the public expressed

128. See, for example, Rabin, 38 Stan L Rev at $1278-95$ (cited in note 3) (describing in "public interest" terms the broad effort of the 1970s to free agency decisionmaking from capture and to reclaim public policy for true public interests).

129. See, for example, id at 1303:

In one way or another, key enactments like the Endangered Species Act, the amendments to the Department of Transportation Act, the Occupational Safety and Health Act, and the Clean Air Act appeared to treat conservation, health, or safety, as the case might be, as a preferred value rather than a consideration of equivalent weight to the economic benefits of regulation.

130. Intermational Harvester, $478 \mathrm{~F} 2 \mathrm{~d}$ at 615.

131. The Federalist No. 10 (Madison), In Jacob Cooke, ed, The Federalist 56-65 (Wesleyan U Press, $1961)$. 
pro-environment opinions and typically only small minorities expressed opinions in the anti-environment direction." 132 It was also reflected in hightone, perhaps unrealistic, rhetoric and in the outpouring of new federal legislation that dramatically restructured the federal role in environmental decisionmaking.

The second element of the distinctive status of environmental quality was that it was treated as an individual right as well as a public good. In this regard, environmental quality was viewed more like civil rights than national defense. To the extent environmental quality is a right, it is an inappropriate candidate for trading off with "mere" interests, such as firm profits, property values, or even wage rates. Again, one piece of evidence for this claim is the public rhetoric of the time, both inside and outside the public arena. A momentary push was even made to constitutionalize a right to environmental quality. ${ }^{133}$

Further support for the "rights" view of environmental quality can be found in the major pollution control statutes enacted at the time. Whereas the economic/public choice view of environmental quality insists that environmental controls be calibrated to balance their benefits with their costs, the Clean Air Act enacted nationally uniform ambient air quality standards, and the Clean Water Act enacted an objective of zero discharge of pollutants into the nation's waters by $1985 .^{134}$ Other provisions, such as the point source limitations under the CWA and the stationary source standards under the CAA, recognized feasibility as a constraint, but did so in circumstances in which the assumption seemed to be that feasibility limited controls would go well beyond the point mandated by cost-benefit analyses. ${ }^{135}$

Finally, environmental quality was considered special in the sense that on more and more occasions the burden of justification was being placed on those who argued against environmental protection, not, as was more typical under the regime of the common law, on those who argued in favor of it. ${ }^{136}$ Federal statutes were read not simply to establish specific programs, but to provide discernible purposes. Thus, in Overton Park, the Court found fault with the secretary of transportation's decision to route a highway through a public park, given a series of recent statutes "designed to curb the accelerating destruction of our country's natural beauty,"137 including one statute which the Court characterized as placing "paramount importance" on

132. Riley E. Dunlap, Public Opinion and Environmental Policy, in James P. Lester, ed, Environmental Politics and Policy 87, 98 (Duke U Press, 1989).

133. See, for example, John C. Esposito, Air and Water Pollution: What to Do While Waiting for Washington, 5 Harv Civ Rts-Civ Lib L. Rev 32, 45-51 (1970).

134. 42 USC § $7409 ; 33$ USC $\S 1311$.

135. Id $\S 7411 ; 33$ USC $\$ 1311$.

136. For example, Martin H. Belsky, Environmental Policy Law in the 1980s: Shifting Back the Burden of Proof, 12 Envir L Q 1, 5-26 (1984); James E. Krier, Environmental Litigation and the Burden of Proof, in Malcolm F. Baldwin \& James K. Page, Jr., eds, Law and The Environment 105 (Walker, 1970).

137. Citizens to Preserve Overton Park, 401 US at 404. 
the preservation of park land. ${ }^{138}$ More generally, according to Judge McGowan:

[h] itherto the right of the polluter was pre-eminent, unless the damage caused by pollution could be proved. Henceforth, the right of the public to a clean environment would be pre-eminent, unless pollution treatment was impractical or unachievable. . . This new view of relative rights . . was based on the widely shared conviction that the nation's quality of life depended on its natural bounty, and that it was worth incurring heavy cost to preserve that bounty for future generations. 199

Judge McGowan's colleague on the District of Columbia Circuit, Judge Wright, put the matter more briefly. The idea, he said, was "to err on the side of caution." 140

4. The Upshot. Optimistic pluralism, agency capture, and the special status of environmental values combined to give judicial review of EPA actions its distinctive early form. During the first few years of EPA's existence, in the midst of a vigorous debate about the proper role of the courts in reviewing agency decisions, ${ }^{141}$ judges tended to emphasize the need to ensure that admiristrative decisions conformed to congressional intent. ${ }^{142}$ During this time, the courts for the most part viewed Congress as the most accountable of the three branches. Agency decisions, because they were made by unelected officiais, depended for their legitimacy on abiding by standards established by Congress, if there were any. ${ }^{143}$ But agency decisionmakers were viewed as susceptible to capture by special interests, and thus as prone to subvert legislative programs. Accordingly, in defining the limits of judicial functions, the courts stressed their obligation to ferret out agency decisions that contravened legislative intent. ${ }^{144}$

Reflecting the special status of environmental protection, the judiciary interpreted the new environmental statutes as giving them "law to apply" in cases in which environmental litigants challenged administrative action as not sufficiently protective of the environment, public health, and safety. In several important cases, the District of Columbia Circuit expressed the view that it was "in a real sense part of the total administrative process." 145 Agency

138. Id at 413 .

139. Weyerhauser Co. $v$ Costle, 590 F2d 1011 (DC Cir 1978).

140. Lead Industries Ass' $n$ v EPA, 647 F2d 1130, 1155 (DC Cir 1980), cert denied, 449 US 1041 (1980).

141. See, for example, the concurring and dissenting opinions in Ethyl Corp., $541 \mathrm{~F} 2 \mathrm{~d}$ at 66, 69,

142. The analysis in this part has focused primarily upon decisions rendered by the United States Supreme Court and by the Federal Court of Appeals for the District of Columbia Circuit, which reviews the bulk of EPA regulatory decisions. See, for example, 42 USC $\$ 7607$ (b)(1) (1988) (petitions for review of certain EPA decisions under the Clean Air Act must be filed in the DC Circuit); 42 USC §6976(a)(1) (1988) (same under RCRA).

143. See Richard J. Pierce, Sidney A. Shapiro \& Paul R. Verkuil, Administrative Law and Process x-xi (Foundation Press, 1985).

144. Id. See generally Sidney A. Shapiro \& Richard E. Levy, Heightened Scrutiny of the Fourth Branch: Separation of Powers and the Requirement of Adequate Reasons for Agency Decisions, 1987 Duke L J 387, 394-95.

145. Kennecott Copper Corp. v EPA, 462 F2d 846, 849 (DC. Cir 1972), quoting Greater Boston Television Corp. v FCC, 444 F 2d 841, 851-52, cert denied, 403 US 923 (1971). 
and court together constituted "a 'partnership' in furtherance of the public interest," 146 as reflected in the environmental legislation EPA was charged with implementing. ${ }^{147}$ The court's "responsibility" as a member of this partnership was to act with restraint, yet provide "supervision" for EPA A $^{148}$ "for the purpose of effectuating the legislative mandate." 149 In short, we had entered a "new era"

[i]n the history of the long and fruitful collaboration of administrative agencies and reviewing courts. For many years, courts have treated administrative policy decisions with great deference, confining judicial attention primarily to matters of procedure. On matters of substance, the courts regularly upheld agency action, with a nod in the direction of the "substantial evidence" test, and a bow to the mysteries of administrative expertise. Courts occasionally asserted, but less often exercised, the power to set aside agency action on the ground that an impermissible factor had entered into the decision, or a crucial factor had not been considered. Gradually, however, that power has come into more frequent use, and with it, the requirement that administrators articulate the factors on which they base their decisions.

Strict adherence to that requirement is especially important now that the character of administrative litigation is changing. . . [C]ourts are increasingly asked to review administrative action that touches on fundamental personal interests in life, health, and liberty. These interests have always had a special claim to judicial protection, in comparison with the economic interests in a ratemaking or licensing proceeding. ${ }^{150}$

Under the influence of this political worldview, the environmental decade of the 1970s also became the decade of the "hard look" and the "soft glance," under which agency decisions disrespectful of environmental interests were more likely to be subjected to intense judicial review and decisions in which the agency had acted to protect the environment or public health under conditions of uncertainty were more likely to receive more deferential treatment. ${ }^{151}$ Despite concessions to the judiciary's lack of scientific and

146. Id at 848 .

147. According to Judge Leventhal, "a unique three-way partnership between the legislature, executive and judiciary, was contemplated by the Congress" and was apparent in the provisions of statutes like the Clean Air Act. International Harvester, 478 F2d at 635.

148. EDF v EPA, 465 F2d at 540-41 (DC Cir 1972). See also Appalachian Power Co. $v$ EPA, 477 F2d 495, 505 n37 (4th Cir 1973).

149. Portland Cement Ass $n, 486$ F2d at 394. Among other things, this supervision would hold EPA to "a high standard of articulation" to ensure that EPA had complied with its obligation to take a "hard look" at the problems involved in its regulatory task. See id; $E D F v E P A, 465$ F2d at 541; Kennecott Copper Corp., 462 F2d 846.

150. EDF $v$ Ruckelshaus, $439 \mathrm{~F} 2 \mathrm{~d}$ at 597. To some, it seemed likely that the nature of the partnership would change over time:

I think we are still in an evolutionary period. It may very well be that what we have is a period of the courts instructing the agencies on how they are to act and how they are to carry out their new environmental responsibilities. We may later come to a retrenchment where the courts pull back, satisfied that the agencies are carrying out their mandates. . .

The better the agencies get, the less the courts will have to do.

Panel, 7 Nat Res L at 370-71 (cited in note 97) (remarks of Grant Thompson). David Sive concluded that judicial review "in depth" was likely to be commonplace at the beginning of the new environmental era because few of the issues to reach the courts would involve the propriety of administrative conclusions concerning undisputed facts arising under a statute whose meaning created little dispute. David Sive, Some Thoughts of an Environmental Lawyer in the Wildermess of Administrative Law, 70 Colum L Rev 612, 621 (1970). He expected this situation to continue "for a considerable period." Id.

151. Both agency capture and the view that environmental values are special contributed to the atrophy of judicial deference to agency expertise and the development of the hard look, but of the 
technical expertise, ${ }^{152}$ the courts apparently took the Overton Park mandate concerning the scope of review of factual matters seriously; the tendency, at least in courts like the District of Columbia Circuit, was toward "thorough, probing, in-depth review"'153 of EPA's scientific determinations. ${ }^{154}$ In response to criticisms that they were overstepping the bounds of both their competence and authority, the judges conducting this kind of review stated that it was not a departure from a court's proper function to peruse carefully the agency record, even as to technical and specialized matters. Indeed, Judge Skelly Wright argued, "[ $t]$ he more technical the case, the more intensive must be the court's effort to understand the evidence, for without an appropriate understanding of the case before it the court cannot properly perform its appellate function." 155 This function was to satisfy itself that the

two, the special character of environmental values may have been the more influential. See Rabin, 38 Stan L Rev at 1299 (cited in note 3):

The erosion of faith in administrative expertise did not in itself trigger the rise of judicial activism in the early $1970 \mathrm{~s}$. Rather, it was the multifaceted concern about environmental issues-fueled, in particular, by the enactment of major new environmental legislation like NEPA and the Clean Air Act-that provided the building blocks for the new foundations of judicial review of administrative action.

152. See, for example, South Terminal Corp., $504 \mathrm{~F} 2 \mathrm{~d}$ at 665 (As laymen, judges are in no position to know how much weight to give to industry's arguments that EPA's measurements of required reductions in air pollutants are without foundation, since the arguments are based on technical assumptions.); International Harvester, 478 F2d at 647 (Courts undertake with diffidence the task of probing into complex technical matters.); id at 651 (Judge Bazelon recognized that he did "not know enough about dynamometer extrapolations, deterioration factor adjustments, and the like to decide whether or not the government's approach to these matters was statistically valid."). Not all of the judges agreed, however, on the implications of the agency's superior expertise. Judge Bazelon emphasized the dangers of rigorous judicial review of scientific and technical matters. De novo evaluation of such matters "inevitably invites judges of opposing views to make plausible-sounding, but simplistic, judgments of the relative weight to be afforded various pieces of technical data." Ethyl Corp., 541 F2d at 66 (Bazelon, concurring). Because he felt that "substantive review of mathematical and scientific evidence by technically illiterate judges is dangerously unreliable," he recommended foregoing such review in favor of attempts to strengthen administrative procedures to improve the quality of agency decisions. Id at 67; see also, Judge Bazelon's opinion in International Harvester, 478 F2d at 651-52. Judge Oakes, on the other hand, rejected the notion that judges were incapable of mastering scientific concepts and terminology. Although they could not be expected to understand a specific problem as well as an EPA scientist, "such depth of understanding is not necessary to decide the lesser question whether an agency has acted arbitrarily or capriciously." Oakes, 7 Envir L Rptr at 50031 (cited in note 75). See also EDF $v E P A, 465 \mathrm{F2d}$ at 541 . Other judges stressed the courts' duty to ensure that the agency has demonstrated careful consideration of even complex technical matters. "A court would abdicate its function were it, when confronted with important and seemingly plausible objections going to the heart of a key technical determination, to presume that the agency could never behave irrationally." South Terminal Corp., 504 F2d at 665. See also Portland Cement Ass'n, 486 F2d at 402 (reviewing courts have a duty to consider whether agency decisions concerning technical matters reflect a clear error in judgment); International Harvester, 478 F2d at 647 (Review of complex technical matters "is an inescapable aspect of the judicial condition.").

153. Citizens to Preserve Overton Park, 401 US at 415 (1971)

154. Judge Leventhal of the D.C. Circuit contended in 1974 that, despite the argument that the technical complexity of the issues in environmental cases should restrict the scope of judicial review, "a fair assessment of judicial developments must put it that in the environmental field the courts so far have been, if anything, fully vigilant to exercise rather than abdicate their supervisory role." Leventhal, $122 \mathrm{U} \mathrm{Pa} \mathrm{L} \mathrm{Rev} \mathrm{at} 512$ (cited in note 76).

155. Ethyl Corp., 541 F2d at 36. 
agency has exercised its discretion reasonably, "with reasons that do not deviate from or ignore the ascertainable legislative intent."156

Review of EPA's statutory interpretations and policy determinations was no less rigorous. In the Aldrin/Dieldrin case, the court devised a "corollary" to the principle that Congress could vest policy choices in EPA: the agency's decisions "must be explained, not merely explainable, in terms of the ingredients announced by [EPA] as comprising the Agency's policies and standards." 157 The court then rejected the agency's recitation of pesticide benefits as an adequate reason for refusing to suspend registration because EPA had failed to consider whether proposed alternatives were available or feasible. ${ }^{158}$

The tendency to skew judicial review toward a more intensive focus on decisions appearing to ignore or downplay environmental concerns was not universal. For example, judicial review of EPA's early implementation of statutes like the Clean Water Act produced a series of decisions in which the Fourth and Eighth Circuits reversed EPA's issuance of technology-based standards because they reflected insufficient consideration of the cost of compliance or had improperly assessed industry's capacity to develop or apply necessary controls. ${ }^{159}$ By the mid-1970s, in cases arising under the Clean Air Act, the courts had also reversed EPA decisions involving a balance of health, technological, and economic factors for giving insufficient consideration to the last two categories. ${ }^{160}$ However, even when they chastised the agency for not properly considering countervailing factors such as cost, the courts employed the characteristic "hard look" profile endorsed in Overton Park. In International Harvester, for example, the District of Columbia Circuit reversed EPA's denial of the automobile manufacturers' application for a suspension of emission standards for light-duty vehicles. ${ }^{161}$ Because, in the court's view, the risks (primarily economic) of an erroneous denial of suspension outweighed the risks (primarily environmental) of an erroneous grant, the court remanded to EPA for reconsideration. ${ }^{162}$ In another case, the same court, sitting en banc, reversed an earlier panel decision invalidating EPA regulations that limited lead content in gasoline. Judge Bazelon's

156. International Harvester, 478 F2d at 648, citing Greater Boston Television Corp., 444 F2d at 850. See also South Terminal Corp., 504 F2d at 655 (though EPA's technical decisions are difficult for nonexpert judges to evaluate, the court must assure itself as best it can that EPA's technical conclusions are as rational as others' conclusions); Portland Cement Ass'n, 486 F2d at 386.

157. EDF $v E P A, 465 \mathrm{~F} 2 \mathrm{~d}$ at 539.

158. Id.

159. See generally George Cameron Coggins \& Thomas O. McGarity, Judicial Review of Technological Standards under the Clean Water Act (American Institute of Chemical Engineers Symposium Series, 1979); Thomas O. McGarity, Media Quality, Technology and Cost-Benefit Balancing Strategies for Health and Environmental Regulation, 46 L \& Contemp Probs 159, 212-17 (Summer 1983).

160. See D. Bruce La Pierre, Technology-Forcing and Federal Environmental Protection Statutes, 62 Iowa L Rev 771, 790, 820, 828 (1977), and cases cited therein.

161. International Harvester, 478 F2d 615.

162. Id at $636,641,648-50$. The court's independent risk balancing was intended to inform the court of what Congress would have intended if it could have foreseen the precise situation confronting EPA and the court. Id at 648 . 
concurrence warned against the temptation, reflected, he said, in both the panel decision and its reversal, to engage in "legislative policy determinations alien to [a court's] true function." 163 Even if such cases did not reflect the view that environmental values were special, they tended to proceed from the premise that the statutes EPA was charged with administering encompassed coherent public policy, and that judicial review was necessary to prevent the agency from deviating from such policy.

In sum, the courts' expressed willingness in the 1970s to intervene more frequently in EPA action reflected all three components of the political vision we have summarized. First, capture theory had undermined general arguments that agencies are entitled to deference. Second, under optimistic pluralism Congress was viewed as a body that could, at least some of the time, produce coherent public policy. Third, the special status of environmental values induced judges to interpret most environmental legislation as being instances where just such a thing had occurred-Congress had enacted statutes with animating purposes that the courts could then deploy as bases to superintend agency workproduct.

\section{Lately: Pessimistic Pluralism, the Ordinary Value of Environmental Protection, and Executive Competence}

1. Pessimistic Pluralism. ${ }^{164}$ The major story in American political theory in the 1970s was the disintegration of optimistic pluralism, precipitated by critiques that exposed two weaknesses in pluralist theory. The first weakness was a fundamental incompatibility between agency capture theory and the idea that competition in the political arena would produce fair and sound social policy, whether the mechanism for doing so was some rather ill-defined tendency toward equilibrium or, as the Legal Process scholars posited, the sage work of the reasonable legislator.

The theory of agency capture assumes that human behavior is importantly influenced by self-interest. The logic of collective action takes that premise and applies it to group behaviors. Capture theorists applied the same premise to agency officials and bureaucrats themselves, and predicted that their actions would reflect self-interested motivations, such as currying favor with lobbies that can help them in expanding the bureau's budget or in supporting them before Congress, making agency jobs less stressful by adopting cooperative rather than adversarial behaviors, and maintaining good relations with potential future employers. In combination, these three behaviors produce systematically redistributive regulation. ${ }^{165}$

163. Ethyl Corp., 541 F2d at 67 (Bazelon concurring). Judge Bazelon, however, concurred in the court's reversal of EPA's suspension decision in International Harvester. See 478 F2d at $650-53$ (Bazelon concurring).

164. One of the authors had coined this term in an earlier manuscript. Having read Eskridge \& Frickey, 48 U Pitt L Rev at 707 (cited in note 60), we must now credit them. We do not know whether it is original to any of us.

165. See text accompanying notes 175-76. 
In contrast, optimistic pluralism posits that legislators will either rationally develop sound social policy or operate as honest brokers in a competitive political marketplace, but it fails to explain from a self-interested perspective why politicians should behave that way. In fact, it seems to exempt politicians from the assumption of self-interested motivation entirely. The conflict between the motivational assumptions of capture theory and optimistic pluralism have been exposed by the recently emergent theory of public choice, which insists that the same assumption of self interest applicable to citizens acting singly, citizens acting in interest groups, and citizens acting in bureaucracies also be maintained with respect to elected officials. According to public choice, "politicians are like the rest of us; their personal, private interests are their fundamental concerns." 166

Once politicians are taken to be as self-interested as bureaucrats, many of the pessimistic conclusions of capture theory ought to apply, ceteris paribus, to the behavior of Congress. ${ }^{167}$ Concentrated interest groups will enjoy systematic advantages in maintaining or improving their positions relative to more dispersed, less concentrated, interests. Concentrated groups will "rentseek," 168 attempting to use the legislative process to lock in economic advantages, so long as the costs of organizing and lobbying to do so are less than the expected benefits of the favorable legislation. ${ }^{169}$

The fact that group interests do not all enjoy equal competitive advantages in the agency world led to the prediction that agencies would be captured by cohesive interest groups. Once captured, the legitimacy of an agency's work product becomes seriously suspect: when a mere subset of affected private interests dominates the bureau's decisionmaking processes, there is no particular reason to confer respect on the decisions thus reached, or to defer to those decisions. The judicial activism of the hard look era constitutes the judiciary's response to this diagnosis. Likewise, if the same dynamics are at

166. Robert D. Tollison, Public Choice and Legislation, 74 Va L Rev 339, 362 (1988). See also Edward Foster, The Balanced Budget Amendment and Economic Thought, 2 Const Comm 353, 366 (1985) ("The theory of public choice rests on the assumption of self-interested behavior by all of the actors in the political process.").

167. A growing body of scholarship traces the consequences of the logic of collective action: and the assumption of self-interested motivation in the legislative context. See, for example, Robert D. Tollison, Public Choice and Legislation, 74 Va L Rev 339 (1988); William N. Eskridge, Politics without Romance: Implications of Public Choice Theory for Statutory Interpretation, 74 Va L Rev 275 (1988).

168. The term "rent-seek"

refers to the attempt to obtain economic rents (i.e., payments for the use of an economic asset in excess of the market price) through government intervention in the market. A classic example of rent-seeking is a corporation's attempt to obtain monopolies granted by government. Such monopolies allow firms to raise prices above competitive levels. The increased income is economic rent from government regulation.

Jonathan R. Macey, Promoting Public-Regarding Legislation Through Statutory Interpretation: An Interest Group Model, 86 Colum L Rev 223, 224 n6 (1986).

169. For example, James M. Buchanan, Robert D. Tollison \& Gordon Tullock, eds, Toward a Theory of the Renl-Seeking Society (Texas A\&M U Press, 1980); Gordon Tullock, The Transitional Gains Trap, 6 Bell J Econ \& Mgmt Sci 671 (1975); George J. Stigler, The Theory of Economic Regulation, 2 Bell J Econ \& Mgmt Sci 3 (1971); Sam Peltzman, Toward a More General Theory of Regulation, $19 \mathrm{~J}$ L \& Econ 211 (1976). An excellent overview of the public choice literature on legislation is Eskridge, $74 \mathrm{Va} \mathrm{L}$ Rev at $275-95$ (cited in note 167 ). 
work at the congressional level, the reasons to respect or defer to legislative decisions diminish. ${ }^{170}$ In particular, the easy complacency of optimistic pluralism that the equilibria reached through the pluralistic legislative process is in some sense "fair" or "sound" can no longer be sustained.171 To the contrary, the results from legislation are "pretty grim."'172 Public goods that the legislature ought to be supplying will not be provided, because demand for them is diffuse and disorganized, while special interest group legislation inevitably will be passed. ${ }^{173}$ We will examine the judicial responses to this diagnosis in a moment. ${ }^{174}$

A major project of public choice theory has been to demonstrate that the actions of government, including the Congress, are generally consistent with the predictions based on the assumption of self-interested motivations. The emerging result is a "redistributive" theory of government, albeit a redistribution with thoroughly negative connotations:

[t]his [redistributive] theory purports to explain many of the activities of modern government as having nothing to do with the public interest-except perhaps at the level of justification and propaganda-but rather to be motivated by attempts to redistribute wealth away from one group and toward another. The favored group need not be, and very often plainly is not, in any sense poor. ${ }^{175}$

The public choice critique of congressional behavior undermines pluralism both procedurally and substantively. Procedurally, the logic of collective action gives systematic advantages to particular privately-motivated actors, thereby generating no a priori confidence in the outcomes of congressional decisions; substantively, studies of particular legislative regimes seem to substantiate the charge that those regimes do, in fact, redistribute wealth toward special interest groups that have no legitimate claim to those resources. ${ }^{176}$

The clash between pessimistic and optimistic pluralism as described to this point is a conflict between theories of behavior. Optimistic pluralism had

170. The "payments" to elected politicians that motivate their self-interested actions "take the form of campaign contributions, votes, implicit promises of future favors, and sometimes outright bribes." William M. Landes \& Richard A. Posner, The Independent Judiciary in Interest Group Perspective, $18 \mathrm{~J} \mathrm{~L} \&$ Econ 875,877 (1975). Compare the types of "payments" bureaucrats are said to receive. See text accompanying notes 101-03.

171. For example, Miller, 77 Am Pol Sci Rev at 735 (cited in note 60) ("That all groups in society are equally likely to be organized and effective in interest group politics is a proposition that has been decisively refuted by both theoretical argument ... and empirical evidence. . . . [T] Thus equilibrium among organized groups' demands-even if such exists and determines political outcomes-merits no particular approbation as fair public policy.").

172. Eskridge, $74 \mathrm{Va} \mathrm{L}$ Rev at 294 (cited in note 167).

173. Id.

174. See text accompanying notes 203-66.

175. William Bishop, A Theory of Administrative Law, $19 \mathrm{~J}$ Legal Stud 489, 498 (1990).

176. See for example, Richard B. Stewart, Regulation in the Liberal State: The Role of Non-Commodity Values, 92 Yale L J 1537, 1540-41 (1983) ("Consider. . . a regulatory system that limits entry to the interstate trucking industry, raises prices to consumers, and gives truckers monopoly profits. On what basis are truckers to be preferred to consumers? If the truckers' advantage reflects nothing but their success in manipulating governmental power to their own purposes . . this transfer [of wealth from consumers to truckers] violates [liberal] neutrality."). For elaboration of this charge in the particular context of environmental legislation, see text accompanying notes 201-02. 
erected a distinction between elected officials and the rest of us with respect to what motivates their actions. When faced with the challenge of justifying the distinction, however, optimistic pluralism found itself singularly illequipped to do so. This was its second weakness.

To respond to public choice theory's challenge, optimistic pluralism needed a coherent alternative theory of what motivated public officials in their official capacities, one that could recommend itself as a way to legitimate actions resulting from those motivations. Historically, republican theories had supplied such an alternative. Republicanism asserts both the necessity of, and the possibility of, citizens possessing and being motivated by public virtues. These virtues prompt citizens to place their decisions within a framework larger than self-interest, a framework that asks what is best for the country. ${ }^{177}$ Such a theory might have provided the starting point for a reply.

When optimistic pluralism looked around for that theory, however, it found itself in much the same position that had worried Sir Thomas More. ${ }^{178}$ Pluralism, developed in a period when ideology had purportedly ended, had implicitly treated all interests that citizens might actually have as equally legitimate and entitled to respect. ${ }^{179}$ The sources of or motivations for pluralistic disagreement were largely exogenous to pluralism's analysis, which concentrated on understanding how a system of dispersed powers and interests mediated those disagreements, without casting any judgments on the merits of them. ${ }^{180}$ Republican ideas, which postulate the existence of an objective public interest, had been submerged, whether through conscious rejection, benign neglect, or some combination of the two. As a consequence, when the pessimists challenged the implicit assumption that politicians behave in the public interest, pluralism lacked even a coherent explanation of what such behavior might look like, let alone a convincing argument that

177. See, for example, Sunstein, 97 Yale LJ at 1539-52 (cited in note 4); Michelman, 100 Harv L Rev 4 (cited in note 61).

178. The law, Roper, the law. I know what's legal, not what's right. And I'll stick to what's legal. ... The currents and eddies of right and wrong, which you find such plain-sailing, I can't navigate, I'm no voyager. But in the thickets of the law, oh there I'm a forester. ... What would you do? Cut a great road through the law to get after the Devil? ... And when the last law was down, and the Devil turned round on you-where would you hide, Roper, the laws all being flat? This country's planted thick with laws from coast to coast-Man's laws, not God's-and if you cut them down ... d'you really think you could stand upright in the winds that would blow then?

Robert Bolt, A Man for All Seasons, Act I, at 65-66 (Random House, 1960).

179. On the end of ideology, see generally, Chaim I. Waxman, ed, The End of Ideology Debate (Funk \& Wagnalls, 1968).

180. See, for example, Lowi, The End of Liberalism at 76 (cited in note 60):

Interest-group liberalism [in which pluralist theory plays a major role] helps solve . . the problem of enhanced conflict and how to resolve it. The politician's contribution to society is his skill in resolving conflict. However, direct confrontations [are typically avoided]. The typical American politician displaces and defers and delegates conflict where possible; he squarely faces conflict only when he must. . . . [Interest-group liberalism] provides a theoretical basis for giving to each according to his claim, the price for which is a reduction of concern for what others are claiming. In other words, it transforms logrolling from necessary evil to greater good. 
politicians would in fact pursue such behavior, because it lacked a theory of public virtue or public values.

Pluralism had constructed a theory in which citizens were perceived as legitimately pursuing through interest groups whatever values they chose. In the course of doing so, it had failed to develop, or to keep current, any explanation for why people make choices other than in their self-interest. When public choice theorists pointed out the obvious-that self-interest certainly is one significant reason people make choices, and politicians are people-pluralism was essentially mute in response. It lacked a theory of public values that could serve as a break against the devil's wind of selfinterest.

Unable to mount a defense against public choice, pluralists tacitly conceded not only that individuals were self-interested, but that every motive was, at bottom, self-interested. The behavioral or motivational thesis of public choice became wedded to a subjective theory of values. By the late 1970s, this marriage was beginning to receive wide recognition within political theory and scholarship. ${ }^{181}$ Not only were "politicians just like the rest of us"182vulnerable to self-interested motivations-but there was "no ascertainable, transcendent 'public interest,' but only the distinct interest of various individuals and groups in society." 183 In short, while early capture theory warned that agencies should be viewed as "subsidizing private interests at the expense of public good," 184 pessimistic pluralism warned additionally that there is not even such a thing as a public good or public interest, only competing private interests. ${ }^{185}$ Somewhat ironically, we have come to call these interests "special" interests, intending thereby to convey that they are

181. See for example, Frank 1. Michelman, Political Markets and Community Self-Determination: Competing Judicial Models of Local Government Legitimacy, 53 Ind L J 145, 148-57 (1977-78).

182. Tollison, $74 \mathrm{Va} \mathrm{L} \mathrm{Rev} \mathrm{at} 362$ (cited in note 167).

183. Stewart, 88 Harv L Rev at 1712 (cited in note 3 ).

184. Wiley, 99 Harv $L$ Rev at 723 (cited in note 99).

185. See, Stewart, 88 Harv L Rev at 1712 (cited in note 3), claiming that by 1975 the courts were already pursuing a policy of assuring "fair representation for all affected interests in the exercise of the legislative power delegated to agencies," and that "[i]mplicit in this development is that there is no ascertainable, transcendent 'public interest,' but only the distinct interests of various individuals and groups in society." Professor Stewart also argues that " 'public interest' lawyers actually represent important but unorganized private interests rather than some transcendent collective interest in the national welfare." Id at $1683 \mathrm{n} 67$. Although he may have been making an empirical observation here, the context suggests he is denying the very possibility of a "public interest."

More recently, while he was assistant attorney general for the Environment and Natural Resources, Professor Stewart wrote more cautiously concerning whether there may be a public interest distinct from the private interests of subgroups of the population. Characterizing the administrative changes he chronicled in the Reformation article as "attempt[ing] to cure Madison's Nightmare" by creating a forum in which all interests could participate, he said that the hope of such changes was "that decisions in furtherance of the public interest would emerge out of the judicially. supervised clash of factions." Richard B. Stewart, Madison's Nightmare, 57 U Chi L Rev 335, 345 (1990). Could it be that Professor Stewart's post as a public servant motivated him to be a little more circumspect in asserting that there is no such thing as a public interest? Maybe, but he had expressed similar sentiments earlier. See Stewart, 92 Yale L J at $1540 \mathrm{nl} 2$ (cited in note 176) (explaining a version of liberalism "premised on a pluralistic conception of the good [that] rejects the view that moral values are wholly subjective and cannot form a rational basis for collective action"). 
not so special, but merely an assemblage of privately motivated parties working in concert.

As they have penetrated deeply into legal scholarship, these pessimistic pluralist ideas have undermined the Legal Process assumption of a reasonable legislator and replaced it with an image of legislator as dealmaker. "Contemporary legal scholarship is haunted by the idea that statutes are nothing more than deals between contending interest groups."186

2. The Environment as an Ordinary Value. What public choice or economic theory means by self-interest needs to be carefully understood. No values germane to a discussion of environmental policy are ruled out by the assumption that individuals behave self-interestedly. Love of family, love of country, altruism, and love of the environment are all permissible motivations or values for self-interested individuals. These values are self-interested as long as the agent perceives that vindicating (or thwarting) them has an effect on the agent's well-being, and acts on them for that reason. ${ }^{187}$ The essential part of the definition of self-interest is that it is self-reflexive: it is the utility or well-being of the individual as perceived by the individual that defines selfinterested behavior.

Once interests or values are grounded in utility, those interests or values are eligible for the kind of egalitarian treatment for which utilitarianism is famous: each one counts for one. Because values are defined with respect to the self-reflexive utility of the individual, no one is justified in claiming that any value is special or unusually entitled to respect or, in republican terms, "public," except by relating that value to individual utilities. In order to have the only kind of value that this theoretical frame recognizes, "values" that an individual asserts must be cashed out in terms of his or her individual utility. Different values may have different rates of utility production for different individuals, or for the same individual at different times. However, even an extremely high rate of utility production for a very large percentage of the population does not make the value more special than any other value.

The normative voice of public choice argues that the utilities of all individuals are entitled to equal consideration as long as the individuals

186. Daniel A. Farber \& Philip P. Frickey, The Jurisprudence of Public Choice, 65 Tex L Rev 873,925 (1987). See also Sunstein, 103 Harv L Rev at 446-51 (cited in note 3) (summarizing the public choice arguments that statutes are private deals and that talk of public purposes is incoherent).

187. See, for example, Ryan C. Amacher, Robert D. Tollison \& Thomas D. Willett, The Economic Approach to Social Policy Questions: Some Methodological Perspectives, in Ryan C. Amacher, Robert D. Tollison \& Thomas D. Willett, eds, The Economic Approach to Public Policy 18, 25 (Cornell U Press, 1976):

Economists take maximizing behavior as a guideline, but they do not limit their consideration of maximizing behavior to economic variables alone; they also tend to look at broader trade-offs among political and other variables. The economist does not view the concept of self-interest narrowly. Individual choice is simply characterized as utilitymaximizing behavior. Many human motivations, including those of love, altruism, and power, result in bchavior that can be regarded as utility-maximizing. 
themselves are so entitled. ${ }^{188}$ While liberal thought in general and pluralism in particular have never acceded to the idea of complete equality of value, ${ }^{189}$ that idea has been deployed to conclude that a wide variety of values, including environmental values, are of equivalent status.

One way to treat environmental values as ordinary is to assimilate them to the economic perspective on social policy decisionmaking. While the economic marketplace does not enable direct trades in individual utilities, it does recognize a single, consistent measure of individual preferences, namely willingness to pay (and, in the case of sellers, willingness to be paid). In our society, many goods and services that people value are traded in the market. Urging that attributes of the environment that people value be traded in the market, or allocated according to market substitutes such as cost benefit analysis, is grounded on the idea that those environmental qualities are ordinary in the same sense as a case of tomatoes or a new car is ordinary.

In this vein, policy analysts argue that "environmental problems are economic problems, and better insight can be gained by the application of economic analysis." 190 Such insight is important, it is claimed, because "we are going to make very little progress in solving the problem of pollution until we recognize it for what, primarily, it is: an economic problem, which must be understood in economic terms." 191

In the 1970s, and more so in the 1980s, more and more arguments over environmental policy advanced an economic understanding of environmental values. Non-economic bases for environmental values were seen as postulating "a set of values [held] to be transcendent and absolute, inherent in the nature of man and therefore ineluctable"192-a version of the worldview that pessimistic pluralists reject. On the other hand, "the economist's model ... seems ... more in keeping with democratic theory in a

188. Theories of subjectively determined values need not hold that individuals are always the best judges of the best means for advancing individual well-being. Individuals might be mistaken in making means-ends connections, so that certain forms of paternalistic behavior on the part, say, of the state might be permissible to override what the individual would otherwise choose to do. Paternalism, however, is fraught with all the problems of knowing others' minds, so that the presumption of such theories is undoubtedly in the direction of consumer or actor sovereignty. Robert A. Dahl, Democracy and lis Critics 65-74, 100-09 (Yale U Press, 1989).

189. See, for example, Steve Shiffrin, who argues liberal societies necessarily do not accord equal status to certain values that the society concludes are destructive or anti-social, such as the value a rapist sees in being able to sexually assault a victim, or the value a thief sees in being able to steal. Steve Shiffrin, Liberalism, Radicalism, and Legal Scholarship, 30 UCLA L Rev 1103, 1147-70 (1983). Ronald Dworkin has advanced an argument for protecting individual rights, regardless of whether doing so diminishes overall utility, in part as a means to screen out "other-regarding" preferences, such as the :.r. ference of a white racist in seeing blacks subjugated, that otherwise might have an unsavory ef i! in a strict utility-maximizing system of social order. Dworkin, Taking Rights Seriously 234-38, 275--s (cited in note 45).

190. William F. Baxter, People or Penguins: The Case for Optimum Pollution 17 (Colum U Press, 1974).

191. Larry E. Ruff, The Economic Common Sense of Pollution, in Robert Dorfman \& Nancy S. Dorfman, eds, Economics of the Environment 41, 41 (W.W. Norton, 2d ed 1977).

192. Charles J. Meyers, An Introduction to Environmental Thought: Some Sources and Some Criticisms, 50 Ind L J 426, 452 (1975). 
pluralistic society,"'193 in which no values are absolute and preferences are pursued in the pluralistic ambience of competition and compromise.

Assimilating environmental values to the economic perspective, hence rendering them ordinary, was behind the much-heralded, but almost completely failed, effort of the early Reagan Administration to privatize public lands. Once a piece of property is placed in private ownership, it becomes available for use and disposition according to the utility-driven preferences of the owner and other potential claimants. If environmental preservation is sufficiently preferred, and a market exists for the effective expression of that preference, the land will be preserved. If, on the other hand, oil exploration is more highly preferred, and markets permit, the land will be put to that use. Environmental protection and environmental values compete on a qualitatively level playing field with all other competing values.

This levelling of values was dramatically illustrated during the Bork hearings, although for an entirely different purpose. In defending his position that Griswold v. Connecticut was an unprincipled decision, Judge Bork compared the competing values involved in the case-the value to the couple to have sexual relations without fear of an unwanted pregnancy versus the value to the majority of a certain moral theory-with another situation in which the competing values would seem self-evidently equivalent. "Compare the facts in Griswold," he argued, "with a hypothetical suit by an electric utility company and one of its customers to void a smoke pollution ordinance as unconstitutional. The cases are identical."194

The electrical company asserts that it wishes to produce electricity at low cost in order
to reach a wide market and make profits... The smoke pollution regulation impairs
[the company's] economic gratifications. The State can assert not only that the
majority prefer clean air to lower prices, but also that the absence of the regulation
impairs the majority's physical and aesthetic gratifications. . . Unless we can
distinguish forms of gratifications, the only course for a principled Court is to let the
majority have its way in both cases. It is clear that the Court cannot make the
necessary distinction. ... Equality of human gratifications, where the [Constitution]
does not impose a hierarchy, is an essential part of constitutional doctrine. ${ }^{195}$

Bork's specific point was to warn the courts away from intervening in majority decisionmaking, but the grounds for doing so reflect the way in which a subjective theory of values, coupled with a liberal assumption of individual equality, produces a levelling of environmental values. Within this framework, desiring to profit from air pollution and desiring to profit from clean air are but equal human gratifications because each is the manifestation of the subjectively determined values of individuals who are entitled to equal status. Majoritarian decisionmaking controls in such cases more or less by default, since the only way to decide what to do is to do what the greater number desire.

193. Id at 452-53.

194. Robert H. Bork, Neutral Principles and Some First Amendment Problems, 47 Ind L J 1, 9 (1971), discussed in Bork Hearings at Part 1, 114-15 (cited in note 42).

195. Bork, 47 Ind $\mathrm{L} J$ at 10 (cited in note 194). 
Employing the economic model to resolve environmental conflicts is, of course, extremely difficult. Unless satisfactory markets can be created, market surrogates like cost-benefit analysis become the usual instrument of choice, yet developing credible analytic techniques for complex environmental decisions continues to be shrouded in controversy. ${ }^{196}$ Nevertheless, the widely shared belief that cost-benefit analysis is, in principle, the correct approach to resolving environmental controversies confirms the movement toward treating environmental values as ordinary.

Studies of the legislative process have similarly promoted the view of environmental values as ordinary. These studies have documented several characteristics of environmental legislation that should have been obvious in any event. First, almost all environmental legislation bestows discrete benefits on some groups in society and discrete detriments on others. For example, nationally uniform emissions standards for new air polluting sources benefit Rust Belt states at the expense of Sun Belt states. If polluters were regulated exclusively according to ambient air quality conditions, the Sun Belt states would be able to attract new industry by offering them lower cost locations than Rust Belt states, who would be forced to impose much stricter emissions standards to reflect the fact that their air is already much dirtier. Environmental statutes provide ample additional examples of provisions that have markedly disparate impacts throughout the country. ${ }^{197}$

Second, environmental statutes bestow differential class benefits, as well. It appears that much environmental protection favors middle class and upper middle class groups at the expense of lower class groups. ${ }^{198}$ The middle class prefers environmental amenities to job growth, for instance, because they feel fairly secure in their job positions and have largely satisfied basic necessities and other preferences. They are ready to expand their search for value to relative luxuries such as wilderness hiking. The poor, on the other hand, differentially prefer jobs to stringent environmental controls. Since they live in already well-polluted urban areas, they prefer economic growth to stagnation. (Perhaps they also intuitively subscribe to Aaron Wildavsky's view that "richer is healthier.")

These studies reinforce the characterization of environmental values as ordinary. To the extent distinct "special interests" benefit from environmental legislation, it becomes attractive to incorporate such legislation into the special interest, "redistributive" theory of government 199 where private, self-interested groups organize to extract private gains from government.

196. See Sidney A. Shapiro \& Thomas O. McGarity, Not So Paradoxical: The Rationale for TechnologyBased Regulation, 1991 Duke L Rev 729.

197. See, for example, Bruce A. Ackerman \& William Hassler, Dirty Air and Clean Coal (Yale U Press, 1981), describing Senator Byrd's successful efforts to require universal scrubbing of coal, thus severely diminishing the economic advantages that cleaner Western coal would have had over dirtier coal from Eastern states. including Senator Byrd's West Virginia.

198. For example, see Stewart \& Krier, Environmental Law E Policy $71-73$ (cited in note 107).

199. See text accompanying note 175 . 
Analyses of congressional voting behavior further reinforce this characterization, because they reveal senators and congresspeople behaving with respect to environmental legislation in just the self-interested manner that the pessimistic pluralist theory predicts. For example, when differential geographical benefits are at stake, congressional voting patterns fall out along remarkably congruent geographical lines, suggesting that congresspeople are aware of the legislation's geographic implications, and that they vote consistently. with the theory of pessimistic pluralism. ${ }^{200}$

Self-interested political behavior can be documented at the micro-level, the level Congress refers to as the "pork-barrel." The Senate version of the 1990 Clean Air Act Amendments provides a timely case study. As it emerged, it bore the marks of "a special interest feeding frenzy," in the words of National Resources Defense Council attorney Richard Ayres. ${ }^{201}$ The list of specially crafted loopholes in the environmental protection measure goes on and on:

West Virginia and Ohio will get billions of dollars to build "clean coal" plants. Steel mills in a few states will have 30 years to control poisonous emissions, instead of the 10 years given other industrial polluters. Florida power companies will get a $\$ 400$ million, 10-year break on pollution control costs.

Sen. Lloyd Bentsen, a Texas Democrat, arranged for a national center to study toxic pollution to be created in Houston. Colorado Sens. Timothy Wirth, a Democrat, and William Armstrong, a Republican, got money to establish centers in Colorado for the study of high-altitude pollution from autos and trucks. And Sen. Alan Simpson, a Wyoming Republican, arranged for a $\$ 750,000$ acid rain research project to be steered to the University of Wyoming.

Sen. Bob Dole of Kansas sponsored an amendment that requires oil companies to buy grain to produce ethanol, a less polluting fuel. Although the oil companies and the Bush Administration opposed the measure and viewed it as a giveaway to a few big agriculture conglomerates, the opposition withered in the face of Dole's influence. Dole also backed the amendments exempting most toxic chemicals used by farmers. In the language of Congress, several senators were given "fixes" for their status. . . . The case of Senator Quentin Burdick, a North Dakota Democrat who is chairman of the Environment Committee, shows how one senator's influence can shape a major piece of legislation. Burdick exempted his state's worst polluting power plants from the bill. ... His state would be the only one in the lower forty-eight to be exempted from key parts of the acid rain central laws, saving hundreds of millions of dollars for the owners of the five worst-polluting plants....

Through the allocation of extra "pollution control credits," [Burdick's amendment would effectively exempt] power plants fired by lignite coal from the acid rain law in states in which every county is in compliance with current clean air laws. Only North Dakota fits that description. With a few senators on the floor, the amendment was discussed for a few minutes. No one objected and the provision was approved without a roll-call vote.

Burdick declined to be interviewed. His spokesman, Joan Brodshaug, said that North Dakota deserved the exemption because it meets all clean air laws and because the state would have been economically harmed if the five plants representing one-fourth of the state's power had been required to comply with the clean air laws.

200. B. Peter Pashigan. Environmental Protection: Whose Interests are Being Protected?, 23 Economic Inquiry 551 (1985).

201. Michael Kranish, Politics and Pollution, Boston Globe 1 (April 9, 1990). 
"The goal of this bill is to improve the health of Americans," she said. "North Dakota doesn't need to because all of our counties are in compliance with clean air laws." Environmentalists said, however, that North Dakota's clean air compliance has nothing to do with the issue because pollutants from power plants are often sent outof-state by the wind. "To have a special exemption for one state is completely unwarranted," environmental lobbyist Ayres said. "I assume he got it because he is chairman of the committee." 202

It would appear that the senators saw little distinction between the Clean Air Act and a fight over which defense installations to close, or an appropriation for public works projects. The pork tastes as good, from whichever barrel it comes. Each constitutes an opportunity to benefit the groups or interests that can in turn benefit the politician.

3. Executive Competence. The political landscape just sketched differs in two crucial respects from the topographical map in place at EPA's creation. First, pessimistic pluralism depicts Congress as a prominent source of society's troubles, instead of a reasonable composer of pluralist differences with the capacity to articulate and enact coherent public policy. Second, casting environmental protection as an ordinary value, in no sense special to society, facilitates assimilating environmental legislation into the general redistributive theory of government. Environmental legislation cannot be considered a counter-example to the pessimist's picture.

We have argued that a conception of the legislative process and its output is essential to a theory of judicial review. ${ }^{203}$ These two changes in the political environment would be enough to prompt a reconsideration of the appropriate role of judicial review, as well as of the costs and benefits of such review. Yet another change has been occurring, however: at the same time that Congress's policymaking capabilities have been disparaged, the belief that the executive is competent to develop sound public policy has been enjoying something of a renaissance. The cumulative effects of these three developments has been a general trend toward a more restrained approach to review of EPA decisions. ${ }^{204}$ This trend can be traced in the Supreme Court's important Chevron U.S.A., Inc. v. NRDC decision.

Chevron upheld a decision by EPA to interpret the term "source," as applied to the nonattainment provisions of the Clean Air Act, to permit the use of the bubble concept. ${ }^{205}$ That EPA decision, made during President Reagan's first term, reversed the position taken on the question by the preceding Carter Administration. The new interpretation was consistent with the clear early interest of the Reagan Administration to minimize

202. Id

203. See text accompanying notes 70-73, 167-73.

204. One can, of course, find exceptions to the general rule. See for example, NRDC v EPA, 907 F2d 1146 (DC Cir 1990) (reflecting comprehensive analysis of legislative history to determine whether EPA's statutory interpretation was correct); EDF $v$ EPA, 898 F2d 183 (DC Cir 1990) (remanding to EPA Clean Air Act regulations for failing to consider adequately statutory factors).

205. 467 US 837 (1984). Under the bubble concept, a polluter may increase pollution at one point in a plant without triggering expensive pollution control requirements if reductions elsewhere at the plant offset the increase. Id at 855-57. 
governmental interference in private affairs and economic development, because bubbling would allow sources locating in nonattainment areas an additional avenue to avoid complying with expensive pollution abatement requirements.

In upholding the new interpretation, the Court enunciated a now familiar two-step analysis, which requires that in addressing issues of statutory interpretation, the court first inquires "whether Congress has directly spoken to the precise question at issue." ${ }^{206}$ If it is addressed, the court simply must effectuate that intent, regardless of the agency's views. If not, then the court's second task is to inquire whether the interpretation of the agency responsible for implementing the statute is reasonable. If it is, the court must defer to it rather than "simply impo[sing] its own construction on the statute." 207 In Chevron itself, since EPA's interpretation represented a "reasonable accommodation of manifestly competing interests," 208 the Court was bound to accept this interpretation. The fact that this constituted a reversal of an earlier policy position posed no special obstacle to judicial deference, for "an agency to which Congress has delegated policy-making responsibilities may, within the limits of that delegation, properly rely upon the incumbent administration's views of wise policy to inform its judgments." 209

Cheuron, which has been described as a "watershed" opinion, 210 differs from the early cases that postulate a judiciary/agency partnership in their conception of how the modern administrative state should fit into the framework of our tripartite system of government. While not unprecedented, Chevron "invalidated what had been a rather common judicial method of overwhelming agency interpretations" of their statutes. ${ }^{211}$ In particular, its rationale evidences no recognition of the possibility that, in the face of statutory failure to speak to the precise question at issue, a court might nevertheless draw on its understanding of the overall purposes or policy objectives of the statute to evaluate the agency's interpretation.

Eschewing a search for legislative purposes in this way is consistent with the pessimistic pluralist view of the legislative process as a "continuous series of bargains," with any discrete piece of legislation being simply the "final agreements hammered out by these factions," on this particular occasion. ${ }^{212}$ Thus, Chevron's proponents typically begin defending the two-step framework for analyzing statutory interpretation issues by recognizing that legislation is the product of a struggle among competing interests and values. ${ }^{213}$ Kenneth Starr, for example, while still a court of appeals judge, argued that "statutes

\footnotetext{
206. Id at 842 .

207. Id at 843 .

208. Id at 865 .

209. Id.

210. Kenneth W. Starr, Judicial Review in the Post-Chevron Era, 3 Yale J Reg 283, 283 (1986).

211. Id at 295. Solicitor General Starr's article contains an excellent review of the precedents prior to Cheuron.

212. Daniel B. Rodriquez, The Substance of the New Legal Process, 77 Cal L Rev 919, 922 (1989).

213. 467 US at 847 (Clean Air Act involved struggle between interests seeking to reduce pollution rapidly and interests concerned that strict controls would retard industrial development).
} 
are rarely, if ever, unidimensionally directed towards achieving or vindicating a single public policy." 214 Complex statutes, like the Clean Air Act, contain many issues around which interests have clashed, compromised, and settled on language. Each provision of these statutes is simply an agreement about a particular item, and it should be construed as a court might construe a contract. Although, according to this view, legislation resolves disputes, it does not point in directions. If the statute does not answer the "precise question at issue," 215 it has not spoken at all in a way that the courts can or should use to resolve the question. Even when the members of Congress reach a consensus on broad objectives, they often differ on the means for achieving those goals." ${ }^{216}$ As a result, even if a broad policy goal is "the animating force driving the legislation, achievement of actual passage . . . invariably requires compromise and accommodation."'217 In the process, "tradeoffs inevitably abound. That is what the legislative process is all about.",2 18

The second complementary theme at work in Chevron is the rehabilitation of the legitimacy of agency policymaking. In apparent disregard of the lessons of agency capture, the Court acknowledges that the incumbent administration can give effect to its own views of "wise policy,"219 within the limits of the agency's delegated authority. This statement is either a cynical concession that "policy" is always the product of interest group deals, so that the executive's policy is as good as the Congress's on that score and the term "wise" is being used facetiously, or it is an indication that suddenly the executive branch is not seen as yet another arena in which bargains among interest groups are hammered out, but as the originator of policy that may indeed be "wise," in the old-fashioned sense of being publicly-minded.

Interpreting this aspect of Chevron in the second way squares with efforts to rehabilitate the executive branch that have paralleled the effort to disparage the Congress. As public choice has painted a depressingly pessimistic portrait of Congress, some have responded by rehabilitating the executive branch to a degree that ought to surprise the early proponents of agency capture. ${ }^{220}$ It is almost as if some "Law of Conservation of Respect for Government" has been at work in the academy and on the bench, so that as respect for Congress ebbed it had to flow to another branch.

214. NRDC $v E P A, 822 \mathrm{~F} 2 \mathrm{~d}$ at 113

215. Chevron, 467 US at 843.

216. Board of Governors $v$ Dimension Financial Corp., 474 US 361, 374 (1986). See also Continental Air Lines, Inc. v Department of Transportation, 843 F2d 1444, 1450 (DC Cir 1988) ("But broad consensus on noble objectives represents only the beginning of the legislative process.").

217. NRDC vEPA, 822 F2d at 113. See also Dimension Financial Corp., 474 US at 374 ("The final language of the legislation may reflect hard-fought compromises. ...").

218. Continental Air Lines, 843 F2d at 1450.

219. 467 US at 856.

220. See, for example, the recent symposium, The Presidency and Congress: Constitutionally Separated and Shared Powers, 68 Wash U L Q 485-706 (1990). The conference whose proceedings are reported here was two days long, with the first day devoted to exalting the importance of the unitary executive and the second devoted to Congress-bashing. 
While the drumbeat of capture theory does continue, the positive traits of executive policymaking are being newly appreciated, including the political accountability of the president, agency expertise, ${ }^{221}$ the ability of each specific agency to coordinate its own activities, and the ability of the Executive Office to coordinate domestic policy across agencies.

The cumulative effect of these changes is a reconstructed theoretical case for extreme judicial deference to agency judgments that helps provide the basis for Chevron's two-step framework for analyzing issues of statutory interpretation. ${ }^{222}$ If a legislative resolution of clashing private interests is sufficiently clear in the context of a particular issue raised before an agency responsible for implementing the statute, the agency, and subsequently a court, must, under Chevron's first step, "give effect to the unambiguously expressed intent of Congress." 223 More often, however, the legislature will not state with sufficient specificity how it wants the agency to resolve a particular conflict, either because it never considered the precise question or was unable to reach a consensus on that level. ${ }^{224}$ Chevron recognized that, in these circumstances, it is appropriate for Congress to delegate to the agency the authority to reconcile conflicting statutory policies. ${ }^{225}$ Indeed, in postChevron environmental cases, "Congressional silence is deemed an implicit delegation of power to an agency to make policy choices" that reasonably

221. See, for example, Stewart, 92 Yale L J at $1565 \mathrm{n} 101$ (cited in note 176).

222. While Chevron deference has been the most prominent response to these influences, it is by no means the only one. The political analysis sketched in the text has been endorsed by some scholars and judges who have developed quite different normative conclusions from it. Other proposals for judicial review include:

1. Reviving the delegation doctrine. See, for example, Peter H. Aranson, Ernest Gellhorn \& Glen O. Robinson, $A$ Theory of Legislative Delegation, 68 Cornell L Rev I (1982). The rationale behind this proposal begins with the observation that special interests may frequently prefer the "policy lottery" that results when the Congress passes vague legislation, sometimes because they have been unable to mass a decisive coalition in the Congress for a clear statutory victory, sometimes because vague language in the statute may successfully mask their true self-interested, rent-seeking motives, thus making it less likely that the legislation will stimulate sharp opposition. Requiring legislation to be more specific thus can flush out rent-seeking motivations and make passing such legislation more difficult.

2. Adopting a rule of parsimonious construction. See, for example, Frank H. Easterbrook, Statutes' Domains, 50 U Chi L Rev 533, 544 (1983). Under this proposal, judges should enforce the legislative deals that have been struck but no more. Whenever there exists judicial doubt about whether the statute authorizes an agency to act, the court should conclude that it does not, on the ground that the deal has not been clearly enough reduced to writing to be binding on the courts. The rationale for such a construction rule is that (1) it recognizes the supremacy of the representative branches of government when these branches speak clearly; (2) it fails to romanticize the process of making deals, understanding that the product of legislation is typically to lock in rents for a successful party and that such a result is typically welfare-diminishing; and (3) it employs a presumption in favor of individual freedom from government interference whenever doubt exists about whether a deal has in fact been struck.

3. Interpreting legislation as if it were public-regarding. See, for example, Macey, 86 Colum L Rev 223 (cited in note 168 ).

223. Chevron U.S.A., Inc., 467 US at 842-43.

224. Id at 865 .

225. Id. See also $N R D C$ v EPA, $859 \mathrm{~F} 2 \mathrm{~d}$ at 199 (noting that "it falls to the agency to reconcile competing legislative goals"). 
accommodate conflicting statutory goals. ${ }^{226}$ Such delegations are unobjectionable, according to Cheoron, because:

[W] hile agencies are not directly accountable to the people, the Chief Executive is, and it is entirely appropriate for this political branch of the Government to make such policy choices-resolving the competing interests which Congress itself either inadvertently did not resolve, or intentionally left to be resolved by the agency charged with administration of the statute. ${ }^{227}$

Justice Scalia has written that policy decisions "are supposed to be political ones-made by institutions whose managers change with each presidential election and which are under the constant political pressure of the congressional authorization and appropriations processes."228 The agency's responsibility, he adds, is to act "within the broad bounds of rationality-to follow the popular will, expressed directly and through the political structures of the executive and legislative branches."'229

If a policy question delegated to and resolved by the agency is challenged in court,

federal judges-who have no constituency-have a duty to respect legitimate policy choices made by those who do. The responsibilities for assessing the wisdom of such policy choices and resolving the struggle between competing views of the public interest are not judicial ones: "Our Constitution vests such responsibilities in the political branches." 230

Similarly, in Justice Scalia's view, the courts' obligation to refrain from interfering in an agency's policy judgments thus "has less to do with 'unsuitability'231 than with lack of political accountability.'"232 As the Dictrict

226. Chemical Mfrs. Ass'n v EPA, 859 F2d 977, 984 (DC Cir 1988); Ohio v Department of the Interior, 880 F2d 432, 441 (DC Cir 1989). See also Chevron U.S.A., Inc., 467 US at 843-44 ("If Congress has explicitly left a gap for the agency to fill, there is an express delegation of authority to the agency to elucidate a specific provision of the statute by regulation."); Chemical Mfrs. Ass' $n$ v EPA, 899 F2d 344, 354 (5th Cir 1990) (Congress is deemed to have implicitly delegated to EPA the power to define key statutory terms); Hazardous Waste Treatment Council v EPA, 861 F2d 270, 291 (DC Cir 1988) (EPA's resolution of the tradeoff between conflicting statutory goals "is the essence of the discretion Congress has delegated it.").

227. Cheoron U.S.A., Inc., 467 US at 865-66. Compare Baltimore Gas Eं Elec. Co. v NRDC, 462 US 87,97 (1983) (Resolution of fundamental policy questions lies with Congress, the agencies to which Congress has delegated authority "and, ultimately, the populace as a whole.").

228. Antonin Scalia, Responsibilities of Regulatory Agencies under Environmental Laws, 24 Houston $\mathbf{L}$ Rev 97, 107 (1987).

229. Id at $107-08$

230. Chevron U.S.A., Inc., 467 US at 866, quoting TVA v Hill, 437 US 153, 195 (1978).

231. Proponents of a limited judicial role in reviewing agency decisionmaking, however, also point to the courts' limited institutional capacity to understand the complex technical issues involved in environmental policymaking. See text accompanying notes 256-59.

232. Scalia, 24 Houston L Rev at 107 (cited in note 228). See also F. Henry Habicht, Jr., Responses to Justice Antonin Scalia, 24 Houston L Rev 111,112 (1987) ("Permitting unfettered second-guessing of [an agency's balancing of competing policies] by unaccountable institutions such as the courts would effectively grant them broad policymaking authority and could have serious implications for our constitutional system.').

Some commentators disagree with this view of the political accountability of the courts. Judge Oakes, for example, has argued that both the judicial system itself and the political process assure some degree of judicial political accountability. See James L. Oakes, The Judicial Role in Environmental Law, 52 NYU L Rev 498, 514-16 (1977); Oakes, 7 Envir L Rptr at 50031-33 (cited in note 75) (The "greatest strength of substantive judicial review" is "that it is simply one part of an ongoing political process, in which all sides can seek to influence ultimate outcomes through many channels, in the 
of Columbia Circuit states, this obligation "springs from fundamental principles of separation of powers."233

The Chevron framework for resolving statutory interpretation issues is thus meant to prevent courts from improperly encroaching upon the domain of the political branches. ${ }^{234}$ In situations in which "Congress has not directly addressed the precise question at issue" 235 (Chevron's step two), a reasonable interpretation by the agency typically represents an accommodation of conflicting policies that the legislature desired the agency to balance or reconcile. If a court refuses to defer to such an accommodation on the ground that it is inconsistent with some overriding goal reflected in the legislation, such as protection of the environment, the court runs the risk of tearing apart the legislative compromise. ${ }^{236}$ A court that refuses to defer to an agency's reasonable interpretation under Chevron's step two promotes "revisionist alterations of the final results of the legislative process."237 This presents "anti-democratic dangers," 238 for statutory ambiguity "may well be the deliberate result of competing and warring legislative forces striving to achieve essentially incompatible results in a single piece of legislation."239 Judicial refusal to permit the agency to resolve the ambiguity, and thus to choose among the warring objectives, "portends a judicial supplanting of a key actor in the drama, namely the agency itself, present on stage at Congress' express direction."240 Accordingly, courts must be careful not to transform their proper and limited role into the role assigned to the agency by "searching for the interpretive approach that 'best promotes' the legislative 'purpose' in question." 241 It is the agency's job to choose the optimal

best tradition of democratic pluralism."). See also Stewart, 62 Iowa L Rev at 714 (cited in note 107) (" $[\mathrm{I}] \mathrm{n}$ a few instances, basic defects in existing political processes justify court action beyond the normal bounds of judicial review.").

233. Continental Air Lines, Inc., 843 F2d 1444, 1449.

234. Chevron U.S.A., Inc., 467 US at 843-45, 864-66

235. Id at 843 .

236. See American Mining Congress v EPA, 825 F2d 1177, 1185, 1187 (DC Cir 1987); Continental Air Lines, Inc., 843 F2d 1450. See also Board of Governors v Dimension Financial Corp., 474 US 361, 374 (1986) (Ignoring legislative compromises "prevents the effectuation of congressional intent.").

237. Continental Air Lines, 843 F2d at 1451 . See also id (Chevron formulation reflects concerns "about judicial unwinding of deals struck in Congress.").

238. Id at 1450, 1451. The most forceful advocate of this line of analysis has been Judge Starr, formerly of the D.C. Circuit. His description in a non-environmental case of the dangers of judicial overreaching is typical:

Acts of Congress may well have a unifying theme and central thrust, but the felt necessities of the legislative process inevitably produce more narrowly focused provisions which fail in full rigor to effectuate the overarching goal. And the hard fact remains that it is not the judiciary's assigned task to sit as a modern-day Council of Revision overseeing the administrative state and to cy pres statutory provisions that may not be in full keeping with the spirit that has ... animated Congress. As in other areas, we must bear firmly in mind "the proper-and properly limited-role of the courts in a democratic society."

International Brotherhood of Teamsters v ICC, 801 F2d 1423, 1430 (DC Cir 1986). Judge Starr has made the same argument, though less colorfully, in environmental cases. See American Mining Congress $z$ EPA, 824 F2d at 1187 (DC Cir 1987); NRDC v EPA, 822 F2d at 113. See also Hazardous Waste Treatment Council y EPA, 861 F2d 270, 291 (DC Cir 1988) (Judge Buckley).

239. Continental dir Lines, 843 F2d at 1451.

240. Id.

241. Id. 
tradeoffs among conflicting goals. According to those who endorse the Chevron approach, "[ $\mathrm{t}]$ hat is the essence of policymaking. And if one thing should be clear, it is that courts are not to engage (at least in the arena of judicial review of agency action) in substantive policymaking." 242

The idea that judges must refrain from rewriting legislative deals further explains why, as compared to the earlier environmental cases, the recent cases display little special solicitude for environmental interest groups. Any heightened receptivity to the arguments or objectives of such groups would invite "[l]osers in the Congress (or, more precisely, partial winners who may view themselves as losers) [to] eschew ... the democratic process and instead enter ... the litigation arena."243 Judicial intervention at the behest of these "losers" would thus defeat statutory "goals" by creating a different balance of interests than Congress intended.944

The case for judicial deference reflected in Cheoron has been made even stronger by certain refinements in the theory of pessimistic pluralism as applied to environmental legislation. These refinements have been stimulated by the inability of the logic of collective action to explain why we have witnessed such a flood of environmental protection legislation in the past twenty years. At first blush, it would seem that the interest groups that enjoy organizational advantage in the bargaining over environmental protection legislation are the groups that oppose stringent legislation. Individual firms, industrial firms as groups, and labor organizations all can line up in opposition to tough environmental measures that threaten their economic self-interest, and all would seem better able to tilt legislative deals to their advantage compared with individual citizens concerned about environmental protection and the groups that organize to represent their interests. The former groups share characteristics that should give them collective action advantages: they tend to be fewer in number, hence easier to organize, and the economic burdens of environmental controls are frequently

242. Id. See also Chemical Mfrs. Ass'n v NRDC, 470 US 116, 134 (1985) (Courts "do not sit to judge the relative wisdom of competing statutory interpretations."); National Tank Truck Carriers, Inc. v EPA, 907 F2d 177, 182-83 (DC Cir 1990).

243. Continental Air Lines, 843 F2d at 1450. Professor Jeremy A. Rabkin has decried the tendency of public interest groups in administrative litigation to "obtain something akin to the authority of medieval lords, speaking for their vassals and serfs as their natural representative." Stephen F. Williams, Book Review, 68 Tex L. Rev 1303, 1310 (1990), quoting Jeremy A. Rabkin, ed, Judicial Compulsions: How Public Law Distorts Public Policy 43 (1989). Compare Interview: William Ruckelshaus, 5 Nat Resources \& Envir 36, 38 (Summer 1990) (Citizen environmental groups have played the dominant role in implementing environmental laws by using the courts.).

244. See Hazardous Waste Treatment Council, 861 F2d 277, 283 (DC Cir 1988). At least one judge has concluded that the standing requirement is perhaps applied more liberally "when at stake are the great public policy considerations of insults to our environment." Public Interest Research Group $v$ Powell Duffyn Terminals Inc., 913 F2d 64, 89 (3d Cir 1990) (Aldisert concurring). Judge Aldisert, however, is less certain of this conclusion than he was before the Supreme Court's recent decision finding that an environmental group lacked standing to challenge decisions by the Bureau of Land Management to terminate public land withdrawals. Lujan v National Wildlife Federation, $110 \mathrm{~S} \mathrm{Ct} 3177$ (1990). In Judge Aldisert's view, Lujan "sent a strong signal to all of us: [The Court] was not, repeat not, totally relaxing standing requirements in cases affecting the environment." 913 F2d at 84 (Aldisert concurring). 
highly concentrated on them, hence they have strong incentives to organize. The latter groups, on the other hand, have to coordinate the interests of much broader groups, each of whom suffers relatively minor damage to its selfinterest. If any environmental legislation is produced at all in this context, pessimistic pluralist theory would seem to suggest that it would redistribute wealth away from environmental consumers and toward regulated firms. While some aspects of environmental legislation might fit that description, much of it plainly does not. ${ }^{245}$

This paradox can be partially resolved by bringing politicians themselves back into the analysis. If politicians sense that they can use environmental issues to their electoral advantage, because they have become politically salient for a large number of voters, they may attempt to secure that advantage by promoting stringent environmental legislation. Politicians, indeed, may become electoral "entrepreneurs," supplying the legislative product-tough environmental legislation-that consumers want. ${ }^{246}$

If pessimistic pluralism rested here, it would have offered an explanation of environmental legislation that was still not totally satisfying, because it would not have taken into account any residual role for those still-powerful groups generally opposed to stiff regulation. Pluralism argues that politicians greatly prefer acting on public policy in nonconflictual contexts when they can funnel benefits to favored groups in relative obscurity without risking the ire of disadvantaged groups. ${ }^{247}$ The entrepreneurial story of legislative enactment hardly seems nonconflictual, because regulated interests are going to be well aware whose ox is being gored and, on the assumptions of public choice, will try to do something about it, presumably by expressing displeasure at the politicians who have wronged them.

A more stable explanation for tough environmental legislation becomes feasible once some space is introduced between enacting legislation and implementing it. If Congress can satisfy its environmental consumer constituents by enacting legislation, it may then be able to satisfy its regulated-interests constituency through lax implementation. Less-thanvigorous implementation might be accomplished by writing ample procedural protections into regulatory measures, ensuring that the regulatory process grinds slowly; by under-funding agency enforcement offices and regulation writing staff, or by ignoring deals made between the regulated interests and the agency. However it is done, exploiting the potential gaps between

245. For example, James Q. Wilson, The Politics of Regulation, in James Q. Wilson, ed, The Politics of Regulation 357, 370 (Basic Books, 1980) ("Since the incentive to organize is strong for opponents of [antipollution] policy, but weak for the beneficiaries, and since the political system provides many points at which opposition can be registered, it may seem astonishing that regulatory legislation of this sort is ever passed.").

246. For example, id at 370. Wilson ascribed entrepreneurial status to individuals such as Ralph Nader, and considered such political leaders as Senator Muskie to be a political "ally" of such entrepreneurs. It is fair to consider them both as entrepreneurs-individuals such as Nader consolidating the demand for legislative product, individuals such as Muskie supplying the product.

247. See, for example, Eskridge, $74 \mathrm{~V}$ a L Rev at 285-95 (cited in note 167), and sources cited. 
enactment and implementation effectively allows political entrepreneurs to differentiate their product according to its relevant market.

This account of environmental legislation, refined to take into account the processes of lawmaking and implementation, produces an evaluation of congressional behavior that remains "pretty grim." In this model, Congress is seen as passing stringent legislation to attract environmental consumer support, but it is legislation that Congress does not want enforced as written. Years ago Congressman Jamie $L$. Whitten expressed a similar thought by remarking that "sometimes a fellow might feel that if he writes a law three times as strong as he wants it to be, maybe it will be carried out 100 percent."248 For a while, such legislation was typically described as "aspirational," perhaps implying that it was high-minded, albeit unrealistic;249 lately it has rather been described as "symbolic," suggesting that it was perhaps not even intended to be enforced. ${ }^{250}$

To say that Congress is passing symbolic legislation comes very close to saying that it passes laws not to make public policy. At most, passing a law initiates the process whereby policy will be made. The process continues as the administrative agency struggles to develop "wise policy" in the context of executive branch and congressional oversight that dominates regulatory decisionmaking once formal laws have been enacted.

This interpretation of the policymaking process reinforces Chevron deference; perhaps it even makes that deference constitutionally compelled. If symbolic legislation cannot generally be viewed as a source of policy or public purpose, the only points at which such legislation seems to supply justiciable material are when specific deals can in fact be identified. Carried further, however, the idea that symbolic legislation is not intended to be enforced might suggest that it is not yet functionally "law" at all, in which case courts being asked to interpret the statute would lack any law to apply.

So the interpretation of environmental legislation as merely symbolic further reinforces deference to the executive by practically eliminating legislation as an expression of public policy. Examined from another angle, the matter might be put this way: within the sphere of government action circumscribed by a piece of symbolic legislation, it is impossible to say what public policy is until the regulatory process begins producing regulations and enforcement. If that is so, it is difficult to imagine what role there could be for the courts in reviewing agency output, short of policing constitutional boundaries. The standard premise of such review, namely that courts are to ensure that agencies carry out the policy decisions reached by Congress, would have to be rejected because, by hypothesis, there have been no such

248. Department of Housing and Urban Development-Independent Agencies Appropriations for Fiscal Year 1973, Hearings before the Subcommittee on HUD-Independent Agencies of the House Committee on Appropriations, 92d Cong, 2d Sess 350 (1972).

249. James A. Henderson, Jr. \& Richard N. Pearson, Implementing Federal Environmental Policies: The Limils of Aspirational Commands, 78 Colum L Rev 1429 (1978).

250. John P. Dwyer, The Pathology of Symbolic Legislation, 17 Econ L, Q 233 (1990). 
policy decisions reached until the agency acts, at which time the correspondence between action and policy will be perfect.

4. The Upshot. Pessimistic pluralism, the downgrading of environmental values, and the rehabilitation of the executive branch have combined recently to change the perception and nature of judicial review of EPA action. Whereas in the early cases the courts stressed their obligation to ensure the consistency of administrative decisions with congressional intent, more recently they have focused on their obligation to refrain from making independent policy judgments and from interfering in the decisions of the political branches of government.

The Chevron test for reviewing an agency's statutory interpretations is the centerpiece of this recent shift in judicial emphasis. But the courts have displayed a similar reluctance to second guess the agency's procedural choices, factual determinations, and, to a somewhat lesser extent, statutory implementation, sometimes using the same rationale as the one upon which Chevron's principles are based. Thus, in Vermont Yankee, decided several years before Chevron, the Supreme Court abruptly ended the courts' earlier practice of requiring innovative agency procedures, ${ }^{251}$ concluding that when Congress passed the Administrative Procedure Act, ${ }^{252}$ it intended that the agencies, not the courts, should exercise discretion in determining when "extra" procedural devices should be employed. ${ }^{253}$ Judicial tinkering with the procedures chosen by the agency would "totally disrupt the statutory scheme, through which Congress enacted 'a formula upon which opposing social and political forces have come to rest.',254 According to Professor Donald Stever, Vermont Yankee leaves courts with only two choices in many environmental cases: undertake "the excruciatingly in-depth review" characteristic of the early cases or "essentially abdicat[e] the review function where technical matters are at issue." 255

Recitations of the need to defer to the agency on complex scientific and technical issues have long been commonplace in environmental cases, ${ }^{256}$ and they have continued to appear in the recent cases. ${ }^{257}$ What is more unusual is

251. See text accompanying notes 112-23.

252. 5 USC $\$ \$ 551-559,701-706$ (1988).

253. Vermont Yankee Nuclear Power Corp. v NRDC, 435 US 519, 546 (1978).

254. Id at 547, quoting Wong Yang Sung $v$ McGrath, 339 US 33, 40 (1950). See also id at 549 (Courts should not "impose upon the agency [their] own notion of which procedures are 'best' or most likely to further some vague, undefined public good.").

255. Donald W. Stever, Jr., Deference to Administrative Agencies in Federal Environmental, Health and Safety Litigation-Thoughts on Varving Judicial Application of the Role, 6 W New Eng L Rev 35, 54 (1983).

256. See note 152 .

257. See, for example, Pennsylvania v EPA, 932 F2d 269, 272 (3d Cir 1991); Her Majesty the Queen in Right of Ontario v EPA, 912 F2d 1525, 1534 (DC Cir 1990); NRDC v EPA, 902 F2d 962, 968 (DC Cir 1990); Browning-Ferris Ind. v Muszynski, 899 F2d 151, 161 (2d Cir 1990); Colorado v Department of the Interior, $880 \mathrm{~F} 2 \mathrm{~d} 481,489$ (DC Cir 1989). In NRDC $v E P A, 824 \mathrm{~F} 2 \mathrm{~d} 1211$, the court warned that "it is not for the judicial branch to undertake comparative evaluations of conflicting scientific evidence." Id at 1216. Compare Baltimore Gas $\dot{0}^{2}$ Elec. Co., 462 US at 103 (1983) (reviewing court must be "at its most deferential" when examining predictions within an agency's special expertise, at the frontiers of science). But sec Chemical Mfrs. Ass'n v EPA, 870 F2d 177. 199 (5th Cir 1989), citing Portland Cement 
the kind of explanation for such deference that has begun to surface. The obligation to defer, according to some, stems from more than just the relative competencies of agencies and courts in understanding technically complex matters. As Justice Scalia has pointed out, finding facts is one of the things courts do best. ${ }^{258}$ In his view, an important reason why Congress establishes agencies and vests in them factfinding powers is to produce a decision in which a close question "go(es) to the side favored by the current political climate." 259 A judicial refusal to defer to agencies on factual matters frustrates that legislative objective.

Today, judicial review in environmental cases containing mixed questions of fact and law, which involve the application of statutes and regulations to facts determined by an agency, also proceeds on the assumption that courts have a limited role in assessing the propriety of an agency's policy choices. ${ }^{260}$ Yet the courts seem to have interpreted the Supreme Court's recent description in the State Farm case ${ }^{261}$ of the judicial role in reviewing statutory implementation as an endorsement of the notion that deference does not mean abdication of the judicial responsibility to ensure "reasoned" decisionmaking by the agency. ${ }^{262}$ Indeed, the courts have determined in a significant number of recent decisions that EPA acted arbitrarily or without sufficient explanation. ${ }^{263}$ The persistence of a meaningful judicial role in this context despite the courts' recent emphasis on removing themselves from policy decisions may be attributable to a perception that the Supreme Court has been sending mixed signals in cases like Baltimore Gas $E$ Electric ${ }^{264}$ and State Farm. ${ }^{265}$ As the Fifth Circuit noted recently, the Court's decisions "seem to embody two different approaches that are "analytically in conflict "with the

Ass' $n, 486$ F2d at 402; South Terminal Corp., 504 F2d at 663-66 (The reviewing court "must 'steep' itself in technical matters sufficiently to determine whether the agency 'has exercised reasoned discretion.' ").

258. Scalia, 24 Houston L Rev at 107 (cited in note 228).

259. Id.

260. See, for example, Baltimore Gas $\xi^{2}$ Elec. Co., 462 US at 105-06; Chemical Mfrs. Ass' $n, 870$ F2d at 200 (recognizing judicial limitations in assessing policy decisions). In Continental Air Lines, Inc., 843 F2d 1444, Judge Starr described as "judicial intervention run riot" a court's refusal to respect, in the context of review of statutory implementation, the agency's resolution of conflicting statutory goals. Id at 1452. Carried out correctly, he said, "arbitrary-and-capricious style review does not put the court into the [agency's] driver's seat." Id at 1451.

261. Motor Vehicle Mfrs. Ass'n v State Farm Mutual Auto. Ins. Co., 463 US 29 (1983). In that case, the Court upheld the lower court's decision overturning the National Highway Traffic Safety Administration's rescission of a regulation requiring automobile manufacturers to install passive restraints. The Court deemed the rescission arbitrary and capricious because the agency's explanations were insufficient to comply with its obligation to engage in "reasoned decisionmaking." Id at 52.

262. See, for example, American Mining Congress, 907 F2d at 1187. Compare NRDC v EPA,902 F2d at 988 (court should not blindly accept agency's claim that decisions are still being studied); Chemical Mfrs. Ass in $v$ EPA, 870 F2d at 198 (According deference to an agency's statutory interpretation does not mean "rubber-stamping" that decision.).

263. See, for example, American Mining Congress, 907 F2d at 1187-91; National Tank Truck Carriers, Inc. v EPA, 907 F2d 177, $184-85$ (DC Cir 1990); Chemical Mfrs. Ass in v EPA, 899 F2d at 359-60; . NRDC $\checkmark E P A, 859 \mathrm{~F} 2 \mathrm{~d}$ at 210 .

264. Baltimore Gas E Elec. Co., 462 US 87.

265. State Farm, 463 US 29. 
result that a court of appeals must choose the one it deems more appropriate for the case at hand." "266

This confusion notwithstanding, some judges and commentators, under the influence of pessimistic pluralist political theory, recently have come to view the legislative arena as a battleground among warring private factions. Frequently, those factions are unable to reach a complete accommodation, a task which the legislature instead delegates to the agency. In this view, agency resolution of the policy conflicts Congress left unresolved is appropriate because agency decisions are subject to the supervision of the president, who is directly accountable to the electorate. Judges who adopt this conception of the legislative and administrative process accept the responsibility for calling the agency to task if its decisions conflict with clear and specific legislative intent. Outside this limited context, however, intervention by unelected judges can only interfere with the Constitution's allocation of policymaking responsibility in the political, accountable branches of government. The result has been a shift in emphasis, best reflected in Chevron and its progeny, away from the early focus on the need for judicial supervision of agency conformance to legislative intent and toward the courts' obligation not to interfere with the decisions of the political branches.

\section{IV \\ Evaluating Judicial Review}

The rhetoric and doctrine of judicial review facing EPA has changed significantly since EPA was created in 1970. To this point, this article has focused on the explanations for these changes, by tracing them to a further set of developments in three political assumptions that inform the judiciary's understanding of the legislative process, of the capacities of the executive branch, and of the national importance of environmental values. Judicial review has receded in recent years because the judiciary and the scholarly community that influences judicial thinking have come to embrace a set of political beliefs different from those in place at EPA's creation. To this extent, then, law and politics are not autonomous disciplines.

Explaining these changes entails looking backwards, to their origins. Once we have the changes in mind, we can also look forward to evaluate them. Regardless of their origins, and in light of EPA's present responsibilities and agenda, is less aggressive judicial review superior to more aggressive review? Much of the recent literature on judicial review of administrative action takes

266. Chemical Mfrs. Ass' $n, 870$ F2d at 200, quoting $H$. Craft Clothing Co. $v$ NLRB, 660 F2d 910, 91314 (3d Cir 1981); Pittston Stevedoring Corp. v Dellaventura, 544 F2d 35, 49 (2d Cir 1976), aff'd sub nom, Northeast Varime Terminal Co. "Capulo, 432 US 249 (1977). The court in Chemical Mfrs. Ass 'n suggested that courts determine the appropriate degree of deference in reviewing an agency's statutory implementation by balancing a variety of factors, including the fact-law dichotomy; whether the issue is one concerning which courts or agencies have superior competence: whecher the issue turns on the agency's interpretation of its own authorizing statute; and the validity of the agency's reasoning. 
up the question of the costs and benefits of less aggressive judicial review. ${ }^{267}$ Given the nature of the symposium of which this article is a part, it is useful in our remaining space to turn to the question of evaluation.

If judicial doctrine could be evaluated by reference to criteria that do not engage contested political questions, evaluating judicial review might provide a means of rehabilitating the autonomy of law from politics. If such evaluation were possible, it would be possible to describe a method of legal reasoning that skirts the stormy debates of politics. As a matter of strictly legal professionalism, legal scholars might restrict their function to careful analysis of which doctrines work best, or which seem most effective in accomplishing the aims of the administrative state, regardless of what those aims may be.

In the course of reviewing the pros and cons of aggressive judicial review, we argue that distinguishing law from politics in this way proves no more successful than the previous attempt. The costs and benefits of the institution of judicial review cannot be appraised without taking a position on the same sort of political assumptions we have just finished canvassing. Furthermore, empirical evidence cannot resolve the dispute over the assumptions themselves. Hence, appraising the costs and benefits of judicial review can only occur from within a contestable political perspective.

Although evaluating the costs and benefits of judicial review cannot ultimately be reduced to an empirical process, it would be a serious mistake to underappreciate the important role empirical evidence can play in that task. Whatever the political assumptions, there are important empirical questions to be analyzed. How, if at all, has judicial review transformed agency behavior; how, if at all, does it affect the physical environment; what are its monetary costs, both in the individual case and systemically; and are there alternatives that accomplish at least some of the same functions at less costs? Some interesting work has recently been done to improve our information in these areas. ${ }^{268}$ These and other empirical findings would force at least a partial reappraisal of judicial review even if the political assumptions of the earlier era had remained in place.

In this concluding section, we sketch what we know about the costs and benefits of aggressive judicial review, highlight the junctures at which evaluating costs and benefits depends significantly on political assumptions, identify some considerations that would count against aggressive judicial review even under the earlier political assumptions, and raise several

267. See, for example, Strauss, 1989 Duke L J 538 (cited in note 2); Cass R. Sunstein, On the Costs and Benefils of Aggressive Judicial Review of Agency Action, 1989 Duke L J 522.

268. The studies are of two kinds, case study and statistical. Significant case studies include Jerry L. Mashaw \& David L. Harfst, The Struggle for Auto Safety (Harv U Press, 1990); R. Shep Melnick, Regulation and the Courts: The Case of the Clean Air Act (Brookings Inst, 1983); Marc K. Landy, Marc J. Roberts \& Stephen R. Thomas, The Environmental Protection Agency: Asking the Wrong Questions (Oxford U Press, 1990) ("EPA, Asking the Wrong Questions"); Peter H. Schuck \& E. Donald Elliott, To the Chevron Station: An Empirical Study of Federal Administrative Law, 1990 Duke L J 984. 
questions about the validity and desirability of the assumptions of pessimistic pluralism.

Two broad sets of criteria bear on any evaluation of judicial review: (1) rule of law values of accuracy, consistency with statutory command, predictability, and rational basis; and (2) substantive goals such as efficiency, protection of environmental quality, or income redistribution. ${ }^{269}$

Sometimes these criteria will both be served by the same act of judicial review, but sometimes they will be in conflict. They were in conflict in TVA $v$. $H i l l,{ }^{270}$ where the Court interpreted the Endangered Species Act according to its plain meaning, thereby refusing to permit the Tennessee Valley Authority to complete the nearly completed Tellico Dam when doing so would destroy the habitat of the snail darter, an endangered species. The ruling served rule of law values, because the Congress had self-consciously written a law that admitted of no exceptions, but did not advance the substantive goal of allocational efficiency. On the other hand, in the Cotton Dust decision, ${ }^{271}$ the Court permitted OSHA to set stricter standards for workplace exposure to toxics than a cost-benefit analysis would justify. That decision advanced both rule of law goals and the substantive goal of protecting worker health, because an acceptance of cost-benefit principles in that context would have been contrary to the statute that Congress had enacted, and also would have resulted in less worker protection. ${ }^{272}$

Part of the problem in evaluating the institution of judicial review is that modifications that advance values in one category, for instance by making rulemaking less administratively expensive, can retard values in the other category, for instance by increasing the frequency with which agencies deviate

269. Prior analyses of the value of procedures such as judicial review have employed different categories, typically three or four in number. Roger Cramton, for example, proposes the criteria of accuracy, efficiency, and acceptability; Jerry L. Mashaw, those of accuracy, fairness, and timeliness; Paul Verkuil has suggested fairness, efficiency, and satisfaction; while Cass R. Sunstein favors legality, real-world improvements (a category he subdivides further into efficient resource allocation and eclectic improvements), and legitimacy. See Roger S. Cramton, A Comment on Trial-Type Hearings in Nuclear Power Plant Siting, 58 U Va L Rev 585, 591-93 (1972); Jerry Mashaw, The Management Side of Due Process: Some Theoretical and Litigation Notes on the Assurance of Accuracy, Fairness and Timeliness in the Adjudication of Social Welfare Claims, 59 Cornell L Rev 772, 774-76 (1974); Paul Verkuil, The Emerging Concept of Administrative Procedure, 78 Colum L Rev 258, 280 (1978); Sunstein, 1989 Duke L J at 522-26 (cited in note 267). Each of these combinations has its merits. The organization we have adopted isolates the criteria that appear to be more immune to political considerations (rule of law considerations) from those that appear more politically sensitive (substantive goals). In the remainder of this section, we argue that, in fact, the value or worth of the rule of law considerations cannot be determined independently of political assumptions. See text accompanying notes 273-91. In addition, trade offs across categories also implicate political considerations. See text accompanying notes $270-72$.

270. Tennessee Falley Authority v Hill, 437 US 153 (1978).

271. American Textile Manufacturers Institute, Inc. v Donovan, 452 US 490 (1981) ("Cotton Dust"). The feasibility analysis sanctioned by Justice Brennan's opinion for the court does not always lead to more stringent controls than cost-benefit analysis would, but the opinion seems to have assumed that it would in fact do so in this case, and perhaps in the typical case.

272. As Cotton Dust indicates, conflicts within each of the two sets of criteria can also arise. In Cotton Dust, worker health protection conflicted with allocative efficiency objectives if the regulatory standard were stricter than cost-benefit analysis could justify. See also note 291, suggesting that Cotton Dust might be differently decided today because of the increasing stress on allocative efficiency. 
from congressional policy decisions. These values, if they are to be compared, require some normative or conceptual grid. Otherwise, they are incommensurable. Insofar as such a grid depends upon some vision of the good society, as it would seem it must, political assumptions will be irreducibly implicated.

The intertwining of law and politics in evaluating judicial review runs deeper than this. Even within the broad category of rule of law values, assessing the size or substantiality of rule of law gains or losses depends upon some political understandings.

In the present context, the political question is not whether the rule of law is a value worth preserving. The question is what sort of judicial review preserves that value. Both old school aggressive reviewers and new school passive reviewers accept rule of law orthodoxy: when the rule of law conflicts with substantive goals, a judge's job is to vindicate the rule of law. Absent constitutional constraints, when Congress has made law by enacting legislation, consistency with statutory command is one of the paramount elements of these rule of law values. So, should Congress enact legislation that is environmentally harmful in one respect or another, it is not part of a court's task to improve the substantive consequences of the legislation at the cost of violating the rule of law. By the same token, should Congress enact a law that ignores cost-benefit considerations, it is not part of a court's task to read that legislation to require the balancing of costs and benefits. Command and control regulation gets roundly criticized these days, especially when it pursues best available technology strategies instead of more market-oriented ones, ${ }^{273}$ yet, if Congress enacts such legislation, it would be wrong to expect courts to reinterpret that legislation to permit more market-oriented approaches. ${ }^{274}$ Petitions for the redress of that grievance should be addressed to the policymaking branches. In other words, judges should interpret the law, not legislate from the bench. This much seems to be common ground between the earlier and the later eras of judicial review. ${ }^{275}$

Both sides will agree, then, that any time the judiciary prevents executive branch deviation from the rule of law by deciding a case brought before it, rule of law values have been advanced. Additionally, both sides agree that such judicial decisions can have desirable systematic consequences beyond the specific case. Agencies act in anticipation of the requirements of judicial review. To the extent that judicial readiness to declare what the law is induces agencies to bring their future activities into line with those declarations, rule

273. For example, Bruce A. Ackerman \& Richard B. Stewart, Reforming Environmental Law, 37 Stan L. Rev 1333 (1985).

274. Likewise, Craig N. Oren suggests that the complex detail of legislation like the Clean Air Act "can submerge rather than elucidate policy questions and thus make it impossible for legislature. executive or judiciary alike to address basic policy questions or resolve ambiguity." Craig N. Oren, Detail and Delegation: A Study in Statutory Specificity, 15 Colum J Envir L 143, 146 (1990). Yet it is not in general a function of the judicial office to make complicated statutes more simple.

275. We should stress that the orthodox view summarized here is itself the product of political assumptions about a judge's proper role. They are simply assumptions that have remained constant during a period in which other assumptions have been shifting. 
of law values are advanced further. Anticipating judicial review may simply result in the agency conscientiously carrying out the law as interpreted by the court;276 it may also result in giving needed leverage to those within the agency who urge that available data be seriously considered and carefully analyzed. ${ }^{277}$

These rule of law advantages have to be balanced against two kinds of costs produced by judicial review. For one thing, complying with the requirements of judicial review, even when it is accurately done, is costly, sometimes in ways that have only recently come to be appreciated. Perfecting a record that will survive judicial review may make individual rules too expensive to write, ${ }^{278}$ reducing total agency workproduct, ${ }^{279}$ forcing agency resources away from the rulemaking area into other, less productive forms of regulation, ${ }^{280}$ or thwarting innovative approaches to substantive problems. ${ }^{281}$ Judicial review also may give lawyers undue leverage inside the agency compared to policy experts, economists, or politicians, whose views may be substantively superior ${ }^{282}$ Furthermore, judicial review, operating as it does on a piecemeal basis, seems particularly unlikely to advance the objective of coordinating an increasingly complex environmental policy, let alone of coordinating it with other pressing items on the domestic or foreign policy agendas. ${ }^{283}$ This may be true even when the vast majority of individual decisions are correct.

276. In their statistical study, Professors Schuck and Elliott see this effect as one explanation for why reversals and remands of agency action declined monotonically from 1965 to 1985 . Hard look review may indeed have been hard, but agencies have been adept at coping with it. "As the administrative state has matured, courts and the agencies have come to know one another better; the dictates of administrative law have become clearer; and agencies have found it less difficult to satisfy reviewing courts, at least in the overwhelming body of their caseload that does not lie at the developing frontiers of the law." Schuck \& Elliott, 1990 Duke L J at 1011 (cited in note 268).

277. Pedersen, 85 Yale $\mathrm{L} J$ at 60 (cited in note 108 ).

278. See, for example, Strauss, 1989 Duke L J at 540 (cited in note 2).

279. Id, citing Meinick, Regulation and the Courts 361-73 (cited in note 268).

280. Jerry L. Mashaw \& David L. Harfst, Regulation and Legal Culture: The Case of Motor Vehicle Safety, 4 Yale J Reg 257 (1987); Richard J. Pierce, Two Problems of Administrative Law: Political Polarity on the District of Columbia Circuit and Judicial Deterrence of Agency Rulemaking, 1988 Duke L J 300, 326.

281. The conflict between rule of law in the individual case and the systemic objectives of the rulemaking process parallels an emerging concern within the civil justice system, where it is becoming recognized that fairness or justice in the individual case may conflict with other values, including fairness or justice in the system as a whole. As Judge Newman has observed, "Whether we have too many cases or too few, or even, miraculously, precisely the right number, there can be little doubt that the system is not working very well. Too many cases take too much time to be resolved and impose too much cost upon litigants and taxpayers alike." Jon O. Newman, Rethinking Fairness: Perspectives on the Litigation Process, 94 Yale LJ 1643 (1985). On the systemic problems of civil justice, sce generally, Justice for All: Reducing the Cost and Delay in Civil Litigation (Brookings Inst, 1989).

282. See, for example, Administrative Law Symposium: Question and Answer with Professors Elliott, Strauss, and Sunstein, 1989 Duke L J 551, 551 (worrying about the overjudicialization of the agency). Sce also Landy, Roberts \& Thomas, EPA, Asking the W'rong Questions at 26 (cited in note 268) (Using EPA's revision of the Clean Air Act's ozone standard as a case study, the authors argue that anticipating judicial review resulted in the agency's Final Notice "[being] written as a legal brief for the rule. It is even less informative and self-critical than the earlier document. In sum, it would be very hard for someone to use it to understand either the science or the policy issues.").

283. For example, Christopher C. DeMuth \& Douglas H. Ginsburg, White House Review of Agency Rulemaking, 99 Harv L Rev 1975 (1986) (arguing that White House review generally and OMB review specifically advances goals of coordinating domestic and foreign policy agendas). 
These problems can be exacerbated, and new ones added, once one concedes that courts sometimes err. The second general category of costs that must be accounted for are the costs of error. One element of error costs arises because judges may be substantively less competent than agencies, so that their judicial interpretations may deflect the agency from accomplishing its substantive mandate more effectively.

A second element of error costs arises whenever judges substitute their policies for those of the politically accountable branches. The difficulty in applying this uncontroversial generalization to the field of administrative law occurs when one recognizes that legislative and executive branch policies do not always coincide. When judges substitute Congress's policies for the executive's, they are advancing the rule of law; when they substitute their own policies for the executive's, they are retarding it. Identifying error, and hence what counts as a cost, thus depends crucially on differentiating between judicial actions that substitute the judges' policies for the agency's versus those that substitute (enforce, vindicate, uphold) Congress's values for a threatened departure by the agency. The heart of the disagreement between the two schools of judicial review relates to this differentiation process. The proponents of earlier aggressive judicial review and the proponents of present, less aggressive review both assert that their approach best avoids the second element of error costs by confining courts to the task of "applying law." Indeed, both claim that their approach is necessary if all the law Congress enacts is to be applied. ${ }^{284}$ In particular, both distinguish congressional policy from judicial policy in their own way, in a manner that can be directly linked to the political changes we have been discussing.

In the late $1960 \mathrm{~s}$ and early $1970 \mathrm{~s}$, the prevailing political model of optimistic pluralism and Legal Process assigned Congress the primary policyenunciating role in the environmental area. ${ }^{285}$ Congress's activity was understood as expressing policies and purposes, not merely as cutting particularistic deals among interest groups competing over rents. Agency capture theory abetted this interpretation by breeding a good deal of skepticism about the desirability of giving regulatory agencies too much flexibility to "innovate," fearing that this frequently meant failing to implement congressionally mandated policy. ${ }^{286}$ Overton Park is an example of the hard look review that resulted. Lately, the combination of pessimistic pluralism's attack on Congress as another forum for self-interested bargaining and deals, and the resurgent faith in executive competence has reversed the policymaking pride of place. ${ }^{287}$

284. Compare, for example, Cass R. Sunstein, Judicial Review of Administrative Action in a Conservative Era, 39 Admin L Rev 353, 366-71 (1987) (Chevron departs from the fundamental principle (hat courts decide questions of law) and Stephen Breyer, Judicial Review of Questions of Fact and Law, 38 Admin L Rev 363, 372-82 (1986) (same), with Pierce, 1988 Duke L J 300, 326 (cited in note 280) (Cheuron necessary to limit courts to applying law).

285. See text accompanying notes 60-98.

286. See text accompanying notes 99-123.

287. See text accompanying notes 203-50. 
One way of expressing the idea that Congress is often not making policy worthy of extrapolation and application, but only cutting deals, as well as the idea that the executive is the protector of the general public interest, is to conclude that Congress creates less "law" when it enacts statutes than we previously assumed. This leads immediately to a rule of parsimonious statutory construction, of which Chevron is an expression. If this idea is carried to its extreme, statutes deteriorate to symbolic utterances, suggesting that Congress may not mean to enact any policy whatsoever. ${ }^{288}$ If that is so, judges conscientiously trying to ensure agency compliance with congressional policy have nothing to do, because there is no policy to be applied. Judges who continue to act aggressively must be doing so on the pretext of ensuring agency compliance with congressional policy.

Under pessimistic pluralism, the scope of congressional "law" has been constricted across the entire administrative spectrum. In the environmental context, we have seen an additional and reinforcing shift, away from the earlier treatment of environmental values as entitled to special judicial protection whenever the Congress had enacted legislation designed to achieve it. ${ }^{289}$ Hard look review developed as part of the attempt to ensure that this fragile and important value would not be lost in the halls of the bureaucracies. More recently, environmental protection has been increasingly assimilated to the economic policy model, as but one value among many, and a value to be evaluated just like the others, against an ultimate standard of efficient resource allocation. ${ }^{290}$ If the dominant issues in EPA rulemaking have become economic, or at least a sort of cost and benefit weighing that aspires to be fully quantified, as does the economic model, then executive office oversight, especially through Office of Management and Budget ("OMB"), seems worthy of consideration as a substitute for hard look review, as has been suggested. 291

In sum, the change between the earlier era and the present one, in terms of assessing the rule of law error costs of aggressive judicial review, does not come in the status the judiciary accords to protecting rule of law values. The Justice Marshall who wrote Overton Park ${ }^{292}$ in 1971 and the Justice Stevens who wrote Chevron ${ }^{293}$ in 1984 agree that the rule of law controls substantive

288. See text accompanying notes 246-50.

289. See text accompanying notes $124-40$.

290. See text accompanying notes 187-202

291. See text accompanying note 297. This shift to treating the environment as ordinary can influence statutory interpretation, even if it does not result in a lessening of judicial review altogether. Take the Cotton Dust decision, as an example. Were Cotton Dust to be decided today, there is good reason to think that the Court would interpret the Occupational Safety \& Health Act differently, as tolerating cost-benefit balancing, because of a growing conviction that allocational efficiency is a paramount social goal, into which environmental and health concerns must be fit as one set of benefits, to be merely weighed or traded-off against other costs. See, for example, Sunstein, 103 Harv L Rev at 492-93 (cited in note 3) (arguing that Congress probably never focused on whether costs and benefits should be balanced under the Act, and that a statutory system that requires a finding of significant risk yet precludes cost-benefit balancing is irrational).

292. Citizens to Preserve Overton Park v Volpe, 401 US 402 (1971).

293. Cherron, U.S.A., Inc., 467 US 837. 
goals in the priority ranking of judicial obligations. Rather, the change that has occurred, and that is manifest in these decisions, is a move toward a much more modest sense of what the law is, and of what the statute commands. ${ }^{294}$ Changes in the political model that underlie the agency-judiciarycongressional relationship have resulted in courts in the late period concluding that Congress says less when it enacts a statute than did courts in the early period. ${ }^{295}$ As a result, aggressive judicial review fares less well under rule of law criteria, because there is simply less law for courts to apply. When the range of unreviewable discretionary activity expands, the presumptive desirability of judicial review declines.

Some reappraisal of the costs and benefits of judicial review would have occurred independently of the political changes discussed here. For example, the shift to an emphasis on economic analysis in environmental policymaking should probably have been anticipated all along, but it was submerged in EPA's early years. While the costs of implementing their regulations have always been a concern of the professionals as well as the politicians in the agency, in the early period they could spot a number of opportunities to improve environmental quality where costs seemed eminently justified by the degree of improvement anticipated. These "cherry-picking" opportunities have to a large extent been consumed in the past twenty years, so that the typical regulatory issue now involves considerable economic costs and debatable environmental benefits. ${ }^{296}$ Once regulatory efforts turn to these second- or third-generation problems, the idea that benefits ought to be balanced with costs gains momentum. Agencies are better equipped to conduct complex cost-benefit balances than the judiciary. As a result, judicial efforts to superintend agency balancing processes are perceived to be not terribly successful.

Another example is the suggestion by some that aggressive judicial review is less necessary because we have developed alternative mechanisms to fulfill important rule of law functions. OMB oversight is the most frequent example. ${ }^{297}$ Whatever the merits of the argument, this is the kind of consideration that would need recognition even during the days of the partnership between court and agency.

Finally, one must consider the possibility that further study reveals that, contrary to most assumptions, judicial review has very little impact on ultimate agency actions, perhaps because agencies persist in pursuing their

294. Just as important as this difference are the apparent differences in approaching the question of what to do when a judge becomes convinced that the statute contains no specific command governing the precise question in the litigation before the court. The construction of default rules to govern in such cases is as much a part of a judge's job as interpreting statutes is. For a discussion of how political theory influences both interpretive norms and default rules, see Sunstein, $103 \mathrm{Harv} \mathrm{L}$ Rev at 411-12 (cited in note 3 ).

295. See text accompanying notes 212-18.

296. See text accompanying notes 13-24.

297. For example, some have argued that OMB review under Executive Orders 12291 and 12498 functions as a presidential substitute for aspects of hard look review. See, for example, Strauss, 1989 Duke $\mathrm{L} J$ at 548 (cited in note 2). 
own agendas and practically always find alternative means for doing so. ${ }^{298}$ That conclusion weakens the case for aggressive judicial review from the optimistic pluralist, capture theory, and special environmental values perspective of the early period as well as from the pessimistic pluralist, executive competence, ordinary environmental values perspective of the later period.

Recent trends toward increasingly detailed statutes may also reinforce a case against aggressive judicial review, whichever political assumptions one endorses. From the pessimistic pluralist's view, detailed statutes such as the 1990 amendments to the Clean Air Act substantiate the claim that members of Congress are in the dealmaking business, because very specific trade-offs, compromises, and deals often do lie behind the increasingly complex terms that Congress enacts. ${ }^{299}$ From the optimistic pluralist's vantage point, such statutory detail may make it extremely difficult for judges to ascertain any underlying purpose for the statute, as statutory provisions come more and more to resemble agency rules and regulations, but do not contain the authoritative explanatory statement that accompanies Federal Register publication of major rules. Faced with such specificity without revealed purposes, the optimist need not abandon her assumption that Congress can compose conflicting positions and adopt truly public policies, but she may have to concede that the Congress either did not do so in a particular case or that the policies adopted have become too opaque to be available for purposes of judicial interpretation. In either case, an aggressive search for statutory purposes will be unavailing.

However relatively independent of politics some elements of the costs and benefits of judicial review may be, the nature of much of the debate about aggressive judicial review suggests that the politically dependent considerations remain terribly significant, and perhaps paramount. In recent years, something of a revisionary movement has begun to question each of the assumptions upon which the current preference for less aggressive judicial review is based.

The political assumptions of pessimistic pluralism, executive competence, and ordinary environmental values are far from self-evident, and may inappropriately skew the role of each of the three branches in the implementation of environmental policy. To begin with, the pessimistic pluralist attack on Congress overstates the extent to which environmental legislation is composed of interest group deals. There is no doubt that such legislation involves tough, deal-like trade-offs, ${ }^{300}$ or that environmental

298. Schuck and Elliott suggest reasons why judicial review may be ineffective in this way. See Schuck \& Elliott, 1990 Duke L.J at 1046- 49 (cited in note 268); but available data is inconclusive on the question of the effectiveness of judicial review. Id.

299. See text accompanying notes 27-28, 167-74, 181-86. See also, Frank H. Easterbrook, Foreword: The Court and the Economic System, 98 Harv L Rev 4, 60 (1983) (the more detailed the law, the more evidence of interest group compromise).

300. The acid rain title of the 1990 Clean Air ACt amendments, with its emissions allowance provision, as well as the job retraining provisions of the same statute, are obvious examples. 
protection is the object of self-interested advocacy. ${ }^{301}$ Nevertheless, the environmental legislation of the past two decades has also been the object of public valuation; it reflects the consistently high value that citizens have placed on environmental quality during that time. Furthermore, despite the plethora of deals struck in the legislative negotiating process, one can nevertheless discern a fairly consistent theme in these enactments, something like a mandate to "do as much as is reasonably possible," with Congress often refusing to translate that mandate into a simple cost-benefit formula. ${ }^{302}$

This conclusion about environmental legislation is consistent with more general studies which have shown that legislators tend to behave with mixed motives, sometimes responding to their conception of the public interest, ${ }^{303}$ and sometimes seeking to maximize individual self interest. ${ }^{304}$ So it is inaccurate to insist that, because of the deal-like nature of the legislative product, environmental laws neither can nor do reflect any coherent public policy. Instead of viewing the more detailed pollution control statutes of recent years as no more than an aggregation of discrete bargains among selfinterested legislators, one can interpret them as an attempt, at least in part, to displace earlier, vaguer, and perhaps more difficult to interpret formulations of environmental policy with a series of more concrete strategies for achieving environmentally protective goals.

The flip side of the coin is that the arguments advocating judicial deference to agency policy judgments paint too rosy a picture of the nature of executive branch decisionmaking. For the most part, the same theorists that denigrate legislative "policy" as little more than efforts to promote individual legislators' self interest heap plaudits on the policy decisions emanating from politically accountable and substantively expert officials in the executive branch. ${ }^{305}$ The idea that agencies are susceptible to capture by the intended targets of their regulatory efforts, which predominated in the $1960 \mathrm{~s}$ and $1970 \mathrm{~s},{ }^{306}$ appears to have fallen by the wayside, despite the failure of the

301. The 1990 Clean Air bill is again instructive. Only one midwestern state emerged with an exemption for its power plants from sulphur dioxide emissions reductions requirements-North Dakota, one of whose senators is Chairman of the Senate Environment and Public Works Committee. See text accompanying note 202.

302. See, for example, Christopher H. Schroeder, The Evolution of Federal Regulation of Toxic Substances, in Michael J. Lacey, ed, Govermment and Environmental Politics 263 (Wilson Center Press, 1989); Mark Sagoff, The Principles of Federal Pollution Laws, $78 \mathrm{Minn}$ L Rev 19, 22-44 (1986).

303. See, for example, Michael E. Levine \& Jennifer L. Forrence, Regulatory Capture, Public Interest, and the Public Agenda: Toward a Synthesis, $6 \mathrm{~J}$ L Econ \& Org 167 (1990); Farber \& Frickey, 65 Tex L. Rev 873 (cited in note 186); Joseph P. Kalt \& Mark A. Zupan, Capture and Ideology in the Economic Theory of Politics, 74 Am Econ Rev 279 (1984); James B. Kau \& Paul H. Rubin, Self-Interest, Ideology, and Logrolling in Congressional Voting, $22 \mathrm{~J}$ L \& Econ 365 (1979); Edward J. Mitchell, The Basis of Congressional Energy Policy, 57 Tex L Rev 591 (1979) (all arguing that ideology rather than economic interest has been the dominant factor in congressional voting in certain areas).

304. See, for example, Sunstein, 103 Harv L Rev at 449 (cited in note 3), citing Martha Detherick \& Paul J. Quirk, The Politics of Deregulation (Brookings Inst, 1985). Professor Sunstein also asserts that the argument in favor of treating legislation simply as "deals" is overstated because "[ $t]$ he problems of aggregating multiple desires do not always prevent the ascription of 'purpose' to legislation." Id.

305. See text accompanying notes 203-44.

306. See text accompanying notes 99-123. 
advocates of enhanced executive branch power to demonstrate in any systematic fashion that the same tendencies toward self-interested behavior attributed to legislators do not also apply to agency policymakers. A considerable body of commentary continues to submit that "[a]dministrative agencies have failed to serve as vehicles for democratic aspirations"'307 and that administrators remain vulnerable to the influence of well-organized factions. ${ }^{308}$

The possibility that statutory goals may be subverted by agency officials beholden to or sympathetic with interest groups has not escaped Congress's attention in the context of environmental policy. The 1984 amendments to the Resource Conservation and Recovery Act and substantial portions of the 1986 Superfund Amendments were in large part a response to perceived Reagan Administration efforts to ignore statutory directives or dismantle regulatory programs. ${ }^{309}$ The detailed provisions, statutory hammers, and enhanced citizen suit opportunities included in those and other environmental statutes adopted in the 1980s were designed to minimize the chances for future agency attempts to derail statutory designs. ${ }^{310}$ These provisions appear to be based on the belief that the earlier environmental statutes did reflect discernible, coherent policy, but that the agency was prone to ignore it. To remedy this situation, Congress translated more general policy prescriptions into more specific "deals," which would be harder for the agency to ignore. Because of Congress's recent difficulty in reauthorizing the pollution control statutes, ${ }^{311}$ such responses to problems discovered through legislative oversight can take years to effectuate. If existing legislation indeed incorporates discernible policy, the courts can play a meaningful role in supplementing legislative oversight by invalidating agency decisions made on the basis of factors not committed to the agency's discretion. ${ }^{312}$

The current case against aggressive judicial review is also premised on the assumption that adherence to principles of judicial restraint will prevent the courts from implementing their own policy preferences in violation of separation of powers principles. But, again, this proposition is not selfevident. In fact, a court may appear to be exercising restraint while instead attempting to promote its own idea of optimal public policy. The potential for this kind of subterfuge is especially high when the legislature reaches a

307. Cass R. Sunstein, Constitutionalism after the New Deal, 101 Harv L Rev 421,429 (1987).

308. See id at 448, citing Paul J. Quirk, Industry Influence in Federal Regulatory Agencies (Princeton U Press, 1981); Kay Lehman Schlozman \& John T. Tierney, Organized Inlerests and American Democracy (Harper \& Row, 1986).

309. See for example, Investigation of the Environmental Protection Agency: Report on the President's Claim of Executive Privilege over EPA Documents, Abuses in the Superfund Program and Other Matters, Subcommittee on Oversight and Investigations, House Committee On Energy and Commerce, 98th Cong, 2d Sess (1984).

310. See Shapiro \& Glicksman, 1988 Duke L J at 824-30, 839-40 (cited in note 27).

311. Thirteen years elapsed between the last two sets of substantive revisions to the Clean Air Act.

312. Compare Sunstein, 103 Harv L Rev at 440 n123 (cited in note 3), quoting The Federalist vo. 78 (Hamilton), in Jacob Cooke, ed, The Federalist 528 (Wesleyan U Press, 1961) (an independent judiciary ına be "an essential safeguard" against "unjust and impartial law's"). 
policy decision on a particular issue and delegates the responsibility for implementing it to an agency that disagrees with that policy. In such a situation, the agency may seek to alter the policy judgment reached by the legislature through the tools of statutory interpretation or implementation. If a court sides with the agency's resolution of the policy issue, it may purport to exercise judicial restraint by deferring to the agency, while at the same time seeking to promote its own (and the agency's) conceptions of "wise" public policy, at the expense of a policy chosen by the other political branch. ${ }^{313}$ In short, a court adhering to so-called principles of judicial "restraint" need not be policy neutral. A recent study of the Supreme Court's environmental law decisions of the last twenty years suggests that the exercise of institutional judicial restraint appears to have "left ample opportunity for [judicial] policy preferences to infuse the results of [these] judicial decisions." 314

Thus, the premises and conclusions of pessimistic pluralism, executive competence, and the ordinariness of environmental values are vulnerable to significant criticisms. This does not counsel a simple reversion to all the assumptions of the earlier period, however. To be plausible, the evaluation of aggressive judicial review will need to occur within a more realistic set of political assumptions than optimistic pluralism seems capable of providing. While the behavioral assumptions of pessimistic pluralism are far too cynical, ${ }^{315}$ optimistic pluralism was correspondingly naive about the reasonableness and public-mindedness of public officials. " ${ }^{316}$ "What is needed is a rework of the field which will assign 'capture' and public-interest accounts of regulation to appropriate spheres." 317 In addition, realistic political theory must grapple with issues raised by the recent republican revival and ignored by much of pluralism, and especially with the project of describing public values in a way that makes so-called public-interest motivational theories credible. ${ }^{318}$ Finally, any ascription of "public purposes" to legislative enactments has to acknowledge the conceptual difficulties in ascribing purposes to collective assemblies.

Work on these fronts may well result in acceptance of the propositions just explored, that is, (1) that legislators at least some of the time eschew selfinterested bargaining in favor of an attempt to promote the public interest, and that environmental legislation at least occasionally reflects coherent public policy; (2) that agency officials, including those at EPA, are vulnerable

313. In a situation like this, the court is exercising what might be called "institutional restraint" in that, by deferring to the agency's views instead of making de novo judgments, the court purports to be limiting its own power in relation to the power of another branch of government, the executive. See Richard E, Levy \& Robert L. Glicksman, Judicial Activism and Restraint in the Supreme Court's Environmental Law Decisions, 42 Vand L Rev 343, 349-50 (1989). But if the court ignores the policy determination reached by the legislature in order to service its own preference for the agency's policy, the court is at the same time exercising what might be called "policy activism." Id at 350-52.

314. See id at 363 .

315. See text accompanying notes 164-73.

316. See text accompanying notes 60-68.

317. Levine \& Forrence, $6 \mathrm{~J} \mathrm{~L} \mathrm{Econ} \mathrm{\&} \mathrm{Org} \mathrm{at} \mathrm{167,} 171$ (cited in note 303).

318. See text accompanying notes $177-86$. 
to capture by the same kinds of factions that allegedly dominate the legislative process, according to public choice theory; and (3) that the exercise of principles of judicial restraint does not guarantee policy neutrality by the courts. If so, then the costs and benefits of judicial review should be reassessed in light of them. Not surprisingly, some of the costs that seem substantial under pessimistic pluralist assumptions will recede, while benefits dismissed as inconsequential will begin to appear more weighty. If, for example, judicial restraint is not a guarantor of policy neutrality by the courts, then the distortion of environmental policy that critics attribute to aggressive judicial review can also result with minimalist, detached review. ${ }^{319}$ On the benefit side, the possibility that agency decisionmakers will be captured by special interests cuts against the argument that the rule of law gains arising from aggressive judicial review could be achieved just as well or better through alternatives like OMB review of EPA rulemakings. Perhaps most important, this potential for capture, coupled with the recognition that Congress can and sometimes does make public policy, may restore the legislature, if not back to the predominant "policymaking pride of place" it held during EPA's early years, at least into a position equal to that of the executive. ${ }^{320}$ Rehabilitation of the perception that Congress gives purpose and direction to EPA when it enacts environmental legislation could restore the presumptive desirability of judicial review by enhancing the rule of law gains likely to flow from it.

It took less than twenty years for the political assumptions of the early years of EPA, which helped generate hard look review, to fall prey to the criticisms spawned by pessimistic pluralism. One can speculate whether the political assumptions that ushered in the more recent era of deferential judicial review will have a longer tenure. Given recent criticisms of these assumptions, and assuming that the analysis of environmental values ultimately resists complete assimilation to a cost-benefit calculus, it is reasonable to predict that judicial review doctrines will moderate once more. If so, analysis of judicial review may move to some position in between the unanalyzed self-confidence of Overton Park and Judge Leventhal's substantive review theory, and the overly and mistakenly deferential position characterized by Chevron.

319. We refer again here to the orthodox view that once Congress enacts legislation that embraces a particular policy judgment, it is not the proper function of either a court or an agency to ignore that judgment. See text accompanying note 275 . To do so would be to engage in the same kind of "substantive mistake" that occurs when an "activist" court displaces an agency policy with which it disagrees.

320. See text accompanying notes $210-21$. 
